Maurer School of Law: Indiana University

Digital Repository@Maurer Law

Indiana Law Journal

Volume 97 | Issue 1

Article 4

Winter 2022

\title{
Promoting Regulatory Prediction
}

Jonathan S. Masur

University of Chicago Law School, jmasur@uchicago.edu

Follow this and additional works at: https://www.repository.law.indiana.edu/ilj

Part of the Environmental Law Commons, Law and Economics Commons, and the Legislation Commons

\section{Recommended Citation}

Masur, Jonathan S. (2022) "Promoting Regulatory Prediction," Indiana Law Journal: Vol. 97 : Iss. 1 , Article 4.

Available at: https://www.repository.law.indiana.edu/ilj/vol97/iss1/4

This Article is brought to you for free and open access by the Maurer Law Journals at Digital Repository @ Maurer Law. It has been accepted for inclusion in Indiana Law Journal by an authorized editor of Digital Repository @ Maurer Law. For more information, please contact rvaughan@indiana.edu.

\section{$\Psi$}

JEROME HALL LAW LIBRARY

INDIANA UNIVERSITY

Maurer School of Law
Bloomington 


\title{
Promoting Regulatory Prediction
}

\author{
JONATHAN S. MASUR ${ }^{*}$ \\ JONATHAN REMY NASH ${ }^{* *}$
}

It is essential for environmental protection that private actors be able to anticipate government regulation. If, for instance, the Biden Administration is planning to tighten regulations of greenhouse gas emissions, it is imperative that private companies anticipate this regulatory change now, not a few years from now after they have constructed even more coal-and gas-fired power plants. Those additional power plants will mean more irreversible greenhouse gases, and these plants can be politically challenging to shutter once built. The point is general to private actors making decisions in the shadow of potential government regulation. Better information about future government actions is thus critical for the benefit of both private actors and society at large. In this Article, we consider market-based and non-market-based means by which to generate information about future government action. We find no perfect answer.

We consider three market-based solutions-prediction markets, the use of equity markets to hedge against future government action, and machine-learning and predictive technologies-and three government-based solutions-greater transparency, the development of intellectual property rights in predictive information, and prediction-forcing regulation, which is regulation that requires private actors to make public predictions about future government action. None of these is a panacea. The market-based solutions founder on the limitations and thinness of markets. Government-based solutions come with significant structural downsides related to the division of authority among different levels of government (federal versus state versus local) and different branches of government at each level

* John P. Wilson Professor of Law and David \& Celia Hilliard Research Scholar, University of Chicago Law School. Masur thanks the David \& Celia Hilliard Fund and the Wachtell, Lipton, Rosen \& Katz Program in Behavioral Law, Finance \& Economics for support.

** Robert Howell Hall Professor of Law and Associate Dean for Research, Emory University School of Law; Director of the Emory Center for Law and Social Science; CoDirector of the Emory Center on Federalism and Intersystemic Governance.

We are grateful to Giuseppe Dari-Mattiacci, Luigi Franzoni, Jacqueline Hand, Shi-Ling Hsu, Bruce Huber, Yael Lifshitz, Cherie Metcalf, Felix Mormann, J.B. Ruhl, Jessica Owley, Robert Schapiro, and Alexander Volokh for helpful suggestions and discussions. We benefited from presentations at the annual meetings of the American Law and Economics Association, the Canadian Law and Economics Association, the Midwestern Law and Economics Association, the Society for Environmental Law and Economics, and the Sustainability Conference of American Legal Educators; at a joint session co-sponsored by the Section on Environmental Law and the Section on Securities Regulation on "What Can Securities Regulation Contribute to Environmental Law, and Vice Versa?" at the 2021 annual meeting of the Association of American Law Schools; and at a faculty workshop at Emory University School of Law. We also thank Ugonna Eze, Adam Hassanein, and Angelica Russell-Johnson for excellent research assistance. 
(executive versus legislative). We conclude that prediction-forcing regulation may be the most promising avenue, though it too is likely not a full solution.

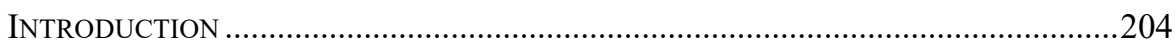

I. THE SOCIAL VALUE OF PREDICTIVE INFORMATION ............................................2208

II. MARKet-Based Solutions to the Problem of

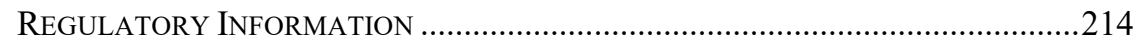

A. The Promise and Pitfalls of Prediction Markets ..........................214

B. EQUITY MARKETS AS HEDGE ..................................................................219

C. Machine Learning And Predictive Technologies ............................221

III. The Role of Government In FACILITATING The Flow of Predictive

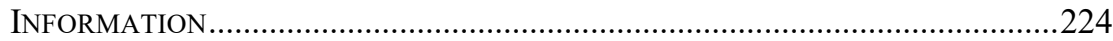

A. HEIGHTENED GOVERNMENT TRANSPARENCY ........................................225

B. INTELLECTUAL PROPERTY FOR PREDICTIVE INFORMATION .....................227

C. Regulation ReQuiring Societal

ACTORS TO ENGAGE IN PREDICTIONS ......................................................2230

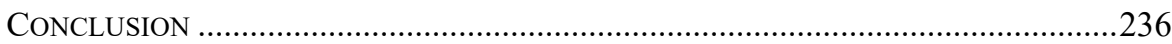

\section{INTRODUCTION}

Imagine an electrical power-generating firm that is contemplating building a new power plant. The firm must decide which type of power plant to construct - a wind farm, a nuclear plant, a natural gas-fired plant, or a coal-fired plant. Each type of plant has advantages and disadvantages for the firm - cost, profitability, etc. And each type of plant has tremendous advantages and disadvantages for the public at large - the cost of electricity generation, the level of greenhouse gas and other pollution emissions, and so forth. ${ }^{1}$ It may be much better for social welfare if the firm decides to construct a wind farm than if it builds a new coal-fired plant. Importantly, however, from the firm's perspective the choice of plant type depends greatly upon the regulatory environment governing electricity generation. ${ }^{2}$ If the government has imposed or will impose substantial regulations on greenhouse gas emissions, a wind farm or even a nuclear plant will represent a far better option than a coal-fired plant

1. See U.S. Energy Info. Admin., Table 8.4. Average Power Plant Operating Expenses for Major U.S. Investor-Owned Electric Utilities, 2009 Through 2019 (Mills per Kilowatthour), ELEC. POWER ANN., https://www.eia.gov/electricity/annual/html/epa_08_ 04.html [https://perma.cc/7L84-6C3G]; How Much Carbon Dioxide Is Produced When Different Fuels Are Burned?, Frequently Asked Questions, U.S. ENERGY InFo. Admin, https://www.eia.gov/tools/faqs/faq.php?id=73\&t=11 [https://perma.cc/4N3V-NY7Y].

2. See, e.g., NextEra Energy, Inc. \& Florida Power \& Light Co., Annual Report (Form 10-K) 22-23 (Dec. 31, 2018) [hereinafter NextEra Energy], http://www.investor.nexteraenergy.com/ /media/Files/N/NEE-IR/reports-andfillings/annual-reports/NextEra\%20Energy_Annual_Report_2018.pdf [https://perma.cc/A85Y-ZHLB]; Duke Energy Corp., Transforming the Future: Duke Energy Annual Report and Form 10-K (Form 10-K) 18-19 (Dec. 31, 2018) [hereinafter Duke Energy], https://www.duke-energy.com//annual-report/_/media/pdfs/our-company/investors/deannual-reports/2018/2018-duke-energy-annual-report.pdf [https://perma.cc/U7PN-HKF2]. 
to the firm. ${ }^{3}$ For that matter, nuclear power is subject to a substantial web of regulations governing both the operation of nuclear plants and the disposal of nuclear fuel. ${ }^{4}$ Depending upon their stringency, these regulations can dramatically raise or lower the cost of constructing a new nuclear plant. ${ }^{5}$

Therefore, in deciding which type of plant to construct, the firm must make a prediction about the regulatory regime that will govern electricity generation in the future. Moreover, the costs of an incorrect prediction could be substantial, both to the firm and to society at large. If the firm constructs a nuclear plant and the government later lifts all greenhouse gas regulations - as the Trump Administration did - the nuclear plant could turn out to be much more expensive than coal-fired plants and be forced out of business. ${ }^{6}$ If the firm constructs a nuclear plant and the government tightens regulations on nuclear power, the nuclear plant might be prevented from ever operating. ${ }^{7}$ The success of the plant - and potentially the fate of the firm - relies on the accuracy of the firm's prediction.

More broadly, the firm's ultimate decision is important to society at large, not just to the firm. If the firm is unable to make an accurate prediction, it will often default to what it believes will be the "safest" option from a financial standpoint. ${ }^{8}$ Here, that

3. See Man-Keun Kim \& Taehoo Kim, Estimating Impact of Regional Greenhouse Gas Initiative on Coal to Gas Switching Using Synthetic Control Methods, 59 ENERGy ECON. 328 (2016) (finding that a regional cap-and-trade regime contributed to a switch from coal-fired power plants to natural gas).

4. See David A. Repka \& Kathryn M. Sutton, The Revival of Nuclear Power Plant Licensing, 19 NAT. RES. \& ENV'T 39 (2005) (providing a summary of the Nuclear Regulatory Commission's process for licensing new nuclear reactors); see also Lucas W. Davis, Prospects for Nuclear Power, 26 J. ECON. PERSP. 49, 54 (2012) ("Most studies attribute this increase in construction time to a rapidly evolving regulatory process. A joke in the industry was that a reactor vessel could not be shipped until the total weight of all required paperwork had equaled the weight of the reactor vessel itself.").

5. See generally John Rust \& Geoffrey Rothwell, Optimal Response to a Shift in Regulatory Regime: The Case of the US Nuclear Power Industry, 10 J. APPLIED ECONOMETRICS S75 (1995) (finding that expected profits from nuclear power plants were almost entirely eliminated by the stronger safety regulations imposed after the Three Mile Island accident).

6. See Repeal of the Clean Power Plan; Emission Guidelines for Greenhouse Gas Emissions from Existing Electric Utility Generating Units; Revisions to Emission Guidelines Implementing Regulations, 84 Fed. Reg. 32,520, 32,521 (July 8, 2019) (to be codified at 40 C.F.R. pt. 60).

7. See Rust \& Rothwell, supra note 5, at S115 (attributing 100 or more cancelled nuclear power plant projects to the more stringent regulatory regime after the Three Mile Island accident); Davis, supra note 4, at 55 ("[I]n 1989 New York Governor Mario Cuomo and the Long Island Lighting Company closed the Shoreham Nuclear Power Plant over long-standing concerns about how nearby residents would be evacuated in the event of an emergency. The plant was 100 percent completed and had been connected to the grid, yet was never used to produce a single kilowatt hour of commercial electricity.").

8. See generally Kira R. Fabrizio, The Effect of Regulatory Uncertainty on Investment: Evidence from Renewable Energy Generation, 29 J.L. ECON. \& ORG. 765 (2013) (finding reduced investment in renewables in states that have a history repealing energy incentive programs in the past); Peter S. Reinelt \& David W. Keith, Carbon Capture Retrofits and the Cost of Regulatory Uncertainty, 28 ENERGY J. 101 (2007) (examining the role that natural gas 
could be a coal-fired power plant, to the detriment of the environment and everyone who breathes the air. In addition, existing corporate investments can be politically difficult to undo. ${ }^{9}$ The government might face stiff opposition if it attempts to shutter a recently constructed coal plant and might default to "grandfathering" the plantthat is, exempting it from new regulation - thus permitting it to spew pollution for decades to come. ${ }^{10}$ All of this is to say that it would be to society's tremendous benefit (and to the firm's) if the firm were able to anticipate future regulation and act accordingly. ${ }^{11}$ We want the firm to cease constructing coal-fired power plants now, not a few years from now when the Biden Administration is finally able to tighten greenhouse gas regulation.

The point is general. Private actors constantly make decisions in the shadow of actions that the government may undertake in the future. ${ }^{12}$ Uncertainty about what those future government actions may be imposes costs. ${ }^{13}$ Private actors may try to hedge their bets, insure against certain contingencies, or simply make decisions without regard to future government actions. ${ }^{14}$ But each of these choices is costly. Better information about future government actions would reduce these costs, to the benefit of private actors and society at large.

This logic leads to the question of how private actors might better be able to make predictions about future government action. We begin by considering three marketbased possibilities. One option is to employ prediction markets - that is, markets that pay investors based on whether future events come to pass - as a means to facilitate predictions about future government action. ${ }^{15}$ Yet prediction markets as to future government action are hard to structure given the division of authority to different levels of government (federal versus state versus local) and different branches of government at each level (executive versus legislative) ${ }^{16}$ Problems of thin markets

prices and regulatory uncertainty play in dictating energy companies' decisions about when to retire existing coal plants).

9. See Saul Levmore, Changes, Anticipations, and Reparations, 99 Colum. L. Rev. 1657, 1665-66 (1999) (describing the political dynamics of legal transitions and the ways in which political actors can oppose transitions that encumber existing assets); Jonathan S. Masur \& Jonathan Remy Nash, The Institutional Dynamics of Transition Relief, 85 N.Y.U. L. REV. 391, 406-28 (2010) (analyzing the various governmental institutions that play a role in provisioning transition relief).

10. Jonathan Remy Nash \& Richard L. Revesz, Grandfathering and Environmental Regulation: The Law and Economics of New Source Review, 101 Nw. U. L. Rev. 1677, 1678 (2007) (discussing grandfathering of pollution sources under the Clean Air Act).

11. Levmore, supra note 9, at 1672-74 (describing the virtues of having a firm anticipate legal change and the desire for policymakers to encourage that anticipation).

12. See, e.g., NextEra Energy, supra note 2, at 22-23; Duke Energy, supra note 2, at 1819.

13. See Fabrizio, supra note 8; Reinelt \& Keith, supra note 8. Cf. Nick Bloom, Stephen Bond \& John van Reenen, Uncertainty and Investment Dynamics, 74 ReV. ECON. STUD. 391 (2007) (finding that instability makes firms more cautious and therefore less responsive to stimulus programs).

14. Reinelt \& Keith, supra note 8.

15. See Masur \& Nash, supra note 9 , at 428-35.

16. See infra Part II.A. 
and market manipulation also abound. ${ }^{17}$ Finally, ethical and legal issues place in doubt whether government employees - who probably have the best information about future government action - could participate in the markets.

One also might think to rely on equity markets as a hedge against future government action. ${ }^{18}$ If a stock - or basket of stocks - would likely increase in value upon a particular government action, why could private actors not invest in that stock or stocks as a way to reduce the risk of the government action in question? The problem here is that corporations are complex entities; their stock prices vary based on a number of factors. ${ }^{19}$ This makes it exceedingly difficult to use stocks to hedge against any one discrete risk.

Nor do machine learning and predictive technologies offer a clear solution. ${ }^{20}$ While they may improve predictions somewhat, the value of those predictions is limited by the available information. And predictive technologies do nothing to dislodge privately held information about future government action. ${ }^{21}$

If prediction markets, equity market hedges, and predictive technologies are not the answer, are there avenues for government to facilitate the ability of private actors to predict future government action? We consider three possibilities: greater government transparency, the development of intellectual property rights in predictive information, and prediction-forcing regulation - that is, regulations that require private actors to make public predictions about future government action. None of these is a panacea.

Greater government transparency seems practically unworkable. ${ }^{22}$ To the contrary, it is reasonable to expect government actors to expend effort to minimize transparency. Moreover, greater transparency may detract from the quality of the laws that are enacted.

The second option, intellectual property rights, suffers from insuperable structural flaws. ${ }^{23}$ The challenges of structuring and enforcing intellectual property rights in predictive information seem insurmountable. The vagaries and multiplicity of possible government actions (let alone the levels of government at which any action might happen) make the definition of property rights exceedingly difficult, costly, or both. Even if the property rights were correctly defined, it would remain challenging for someone who had such a right to enforce it: After all, how exactly would the rights holder prove that someone else had improperly used the information covered by the right?

The third option-prediction-forcing regulation - may be more promising than the others but is hardly free from complications. ${ }^{24}$ An example of a prediction-forcing regulation comes in the form of a 2010 interpretive guidance document promulgated

17. See infra notes $82-89$ and accompanying text.

18. See infra Part II.B.

19. See Benjamin M. Friedman \& David I. Laibson, Economic Implications of Extraordinary Movements in Stock Prices, 1989 Brookings PaPers on ECON. Activity 137 (1989).

20. See infra Part II.C.

21. See infra Part II.C.

22. See infra Part III.A.

23. See infra Part III.B.

24. See infra Part III.C. 
by the Securities and Exchange Commission (SEC), which requires registered public companies to predict future action by various levels of government regarding climate change. ${ }^{25}$ However, the initiative has had little effect on private actors' disclosures. ${ }^{26}$ On the other hand, to the extent that prediction-forcing regulation is effective at requiring public predictions about future government action, it invites private actors to expend effort - for example, by lobbying - to reduce the likelihood of government action. Perversely, actors could lobby governments in favor of some (completely unrelated) actions in order to reduce the likelihood that a particular undesirable government action will come to pass. In short, much as in the setting of greater government transparency, there may be deleterious effects on the quality of the body of law that is enacted.

This Article proceeds as follows. Part I describes and assesses the social value of predictive information. Part II analyzes possible market-based methods to facilitate private predictions about future government action. We address prediction markets, the use of equity markets to hedge against future government action, and the use of predictive technologies. Part III discusses the three options for government to improve private predictions about future government actions: increased government transparency, the development of property rights in predictive information, and prediction-forcing regulation. Our conclusion is that while no approach is perfect, prediction-forcing regulation seems the most promising option.

\section{The Social Value of Predictive Information}

Private actors regularly face decisions that, with complete information, could turn on what the future will bring. The future of the economy is almost always relevant

25. Commission Guidance Regarding Disclosure Related to Climate Change, 75 Fed. Reg. 6290 (Feb. 8, 2010) (to be codified at 17 C.F.R. pts. 211, 231, 241) [hereinafter Interpretation]. Just last year, the SEC opted to keep the Interpretation in place. See Public Statement, Chairman Jay Clayton, Statement on Proposed Amendments to Modernize and Enhance Financial Disclosures; Other Ongoing Disclosure Modernization Initiatives; Impact of the Coronavirus; Environmental and Climate-Related Disclosure (Jan. 30, 2020), https:/www.sec.gov/news/public-statement/clayton-mda-2020-01-30

[https://perma.cc/WB6H-8HKU] (retaining existing framework while urging continued study of the issue); Jane E. Montgomery, SEC Indicates It Will Not Modify Climate Change Disclosure Criteria, NAT'L L. REV. (Feb. 18, 2020), https:/www.natlawreview.com/article/sec-indicates-it-will-not-modify-climate-changedisclosure-criteria [https://perma.cc/NB69-VWGS]; see also U.S. Gov'T AcCOUNTABILITY Off., GAO-18-188, Climate-Related Risks: SEC Has TAKen Steps to Clarify Disclosure REQUIREMENTS 7-9 (2018), https://www.gao.gov/assets/700/690197.pdf [https://perma.cc/37NX-NGJL]; Public Statement, Commissioner Allison Herren Lee, "Modernizing" Regulation S-K: Ignoring the Elephant in the Room (Jan. 30, 2020), https://www.sec.gov/news/public-statement/lee-mda-2020-01-30 [https://perma.cc/2VVDD9VH ] (lamenting that the status quo would persist). In September of this year, the SEC indicated that it may expect more disclosure under the Interpretation. See U.S. SEC. \& EXCH. Comm'n, Sample Letter to Companies Regarding Climate Change Disclosures (2021), https://www.sec.gov/corpfin/sample-letter-climate-change-disclosures

[https://perma.cc/CNN2-XP7Z].

26. See infra Part III.C. 
to private firms: for example, businesses might ask whether the economy will improve or degrade and whether consumer demand for particular items will increase or dissipate. ${ }^{27}$ The future of technological advancement is of similar interest to private actors: businesses might ask whether new technologies will develop, and whether older technologies will be rendered obsolete. ${ }^{28}$ For example, private parties would likely also be concerned about the possibility of other types of events: businesses might ask how many hurricanes, or terrorist attacks, will strike a particular region. ${ }^{29}$

What is a private actor to do in the face of lack of information about the future? An actor could opt to hedge its bets against numerous possible eventualities. The actor could allocate funds and capital and make investments and personnel decisions with an eye to different possible futures. ${ }^{30}$ But such strategies can be very expensive. An actor might also try to hedge its bets by seeking to insure against certain eventualities, i.e., to shift risk about the future to insurers. ${ }^{31}$ But this strategy can be expensive too. And it also turns on the availability of insurance, which itself turns on the ability of insurers to make predictions about the future with some accuracy.

Yet another option is for an actor to ask the government to provide relief from adverse future events that come to pass. This could take the form of governmentfunded insurance in the face of certain catastrophic events ${ }^{32}$ or exceptions from the application of new laws in the face of legal transitions. ${ }^{33}$ But such government programs are inefficient ${ }^{34}$ and costly to administer. ${ }^{35}$ Moreover, while such programs may be introduced as temporary (or otherwise limited in scope) measures, recipients have an incentive to lobby to extend the benefits once they have been introduced. ${ }^{36}$

27. See Louis Kaplow, An Economic Analysis of Legal Transitions, 99 HaRv. L. Rev. 509, 533 (1986).

28. See id.

29. Cf. How to Bet on a Hurricane, Forbes (Aug. 5, 2009, 12:30 PM), https://www.forbes.com/2009/08/05/hurricanes-options-hedging-business-wall-streethurricanes.html\#397d0fb20176 [https://perma.cc/99SA-NLW9].

30. See Söhnke M. Bartram, Gregory W. Brown \& Frank R. Fehle, International Evidence on Financial Derivatives Usage, 38 Fin. Mgmt. 185 (2009); Dimitris Kenourgios, Aristeidis Samitas \& Panagiotis Drosos, Hedge Ratio Estimation and Hedging Effectiveness: The Case of the S\&P 500 Stock Index Futures Contract, 9 InT'L J. Risk ASSESSMENT \& MGMT. 121 (2008).

31. See Kenneth J. Arrow, Essays in the Theory of Risk-Bearing (1971); see also David M. Cutler \& Richard Zeckhauser, Extending the Theory to Meet the Practice of Insurance, BROOKINGS-WHARTON PAPERS ON FIn. SERV. 1 (2004).

32. See, e.g., Scott Gabriel Knowles \& Howard C. Kunreuther, Troubled Waters: The National Flood Insurance Program in Historical Perspective, 26 J. POL'Y Hist. 327, 332-49 (2014).

33. See, e.g., Nash \& Revesz, supra note 10, at 1681-1707 (discussing grandfathering under the federal Clean Air Act).

34. See Kaplow, supra note 27, at 522-36. Various commentators have recognized the propriety of relief from a legal transition under certain appropriate circumstances. See Masur \& Nash, supra note 9, at 398-402 (surveying the literature).

35. See Jonathan Remy Nash, Allocation and Uncertainty: Strategic Responses to Environmental Grandfathering, 36 ECOLOGY L.Q. 809, 822-35 (2009).

36. See Nash \& Revesz, supra note 10, at 1728-30. 
Thus, the costs of such programs are often larger than originally expected and also include costs expended to establish and extend the programs.

Accurate predictive information enables societal actors to make better, more informed decisions, thus allowing them to cut their costs and operate more efficiently; this in turn improves societal welfare. ${ }^{37}$ Even if predictive information does not provide a perfect window into the future (as it inevitably cannot), it can still narrow the set of possible eventualities and suggest that some eventualities are more likely to come to pass than others. It can also turn uncertainties about the future into mere risks, ${ }^{38}$ and it is far easier to hedge, and insure against, risks than uncertainties. ${ }^{39}$ Finally, the availability of accurate predictive information should lower the demand for legal transition relief. To the extent that more accurate information about future government action is available, there would be less need for transition relief since more societal actors would be able to adjust their behavior to the new legal regime in advance. ${ }^{40}$

In short, accurate information about future change-for example, economic, technological, and meteorological change - can aid societal actors in making efficient decisions. A business that recognizes an impending shift in market demand, or a technological advance in the offing, can shift its resources efficiently in advance. ${ }^{41}$ And efficient allocations of resources inure to the benefit of society at large.

The foregoing discussion applies as well to future possible actions by the government. Future legislative actions, regulatory actions, and legal changes are all pieces of information to which private actors would like to be privy. Commentators have emphasized that legal change is much like other kinds of change that challenge private actors and that it is inefficient for private actors not to act with an eye to the future. ${ }^{42}$ Accurate predictions about future legislative actions, regulatory actions, and legal change thus enable actors to behave more efficiently.

37. See, e.g., Burcu Adivar, Tarik Atan, Bengü Sevil Oflaç \& Tuğba Örten, Improving Social Welfare Chain Using Optimal Planning Model, 15 Supply Chain Mgmt. 290 (2010).

38. See, e.g., Henry E. Smith, Property and Property Rules, 79 N.Y.U. L. REV. 1719, 1724 (2004) ("According to Frank Knight's classic distinction, risk is variability in outcomes that can be captured by a probability distribution, but uncertainty cannot be quantified in this way.”) (citing Frank H. KNIGHT, Risk, UNCERTAINTY AND PROFIT 19-21, 197-232 (1921)).

39. See Christian Gollier, Some Aspects of the Economics of Catastrophe Risk Insurance, in Catastrophic Risks and Insurance 13 (Org. for Econ. Coop. \& Dev. 2005); Amos Tversky \& Daniel Kahneman, Advances in Prospect Theory: Cumulative Representation of Uncertainty, 5 J. RisK \& UnCERTAINTY 297 (1992); Kenneth J. Arrow, Uncertainty and the Welfare Economics of Medical Care, 53 Am. Econ. Rev. 941 (1963).

40. Cf. Levmore, supra note 9, at 1665-66 (transition relief arises when a new legal regime would disadvantage politically powerful actors who can credibly threaten to derail the new regime unless they receive transition relief).

41. See Liran Einav \& Jonathan D. Levin, The Data Revolution and Economic Analysis, in 14 InNovation Policy AND the EConomy 1 (Josh Lerner \& Scott Sterns eds., 2014); see also Steven L. Scott \& Hal R. Varian, Bayesian Variable Selection for Nowcasting Economic Time Series, in Economic Analysis of the Digital Economy 119 (Avi Goldfarb, Shane M. Greenstein \& Catherine E. Tucker eds., 2015).

42. See Kaplow, supra note 27, at 534-35 ("A private actor should be indifferent as to whether a given probability of loss will result from the action of competitors, an act of 
As we have explained, the benefits of better information and more accurate predictions will redound not just to the private company but to society at large. ${ }^{43}$ Legal progress will be easier if firms adapt to predicted legal changes ahead of time, as opposed to fighting to preserve the investments they have already made. ${ }^{44}$ The risk diminishes that existing undesirable assets will be grandfathered in, like the coalfired power plant we described in the introduction. ${ }^{45}$ And society gains the benefit of the firm acting expeditiously in advance of the legal change, rather than dragging its feet until the last minute. ${ }^{46}$

In the interests of concreteness, consider the following example. Imagine a private firm that is in the business of manufacturing wind turbines for large-scale electricity generation. (We'll call this firm "Wind Co.") Its major customers are electric utility companies. The firm was started in 2016, after the Clean Power Plan ${ }^{47}$-President Barack Obama's regulation curbing carbon dioxide emissions - made it more expensive to operate coal-fired power plants and dramatically increased demand for wind turbines. ${ }^{48}$ However, the firm struggled financially after the Trump Administration announced that it would repeal the Clean Power Plan. ${ }^{49}$ Wind Co. must decide what to do now that Joe Biden has assumed the presidency. If the Clean Power Plan remains in force (or is strengthened), ${ }^{50}$ Wind Co. should expand its operations to meet rising demand. For that matter, individual states might promulgate their own power-generation regulations, which could have the same effect. And if

government, or an act of God, except to the extent that the source of the risk will affect the likelihood of compensation or other relief.").

43. See Jeffrey R. Brown \& Jiekun Huang, All the President's Friends: Political Access and Firm Value, 138 J. Fin. ECON. 415 (2020).

44. See Levmore, supra note 9, at 1682-84 (describing the ways in which entrenched interests might form political coalitions in an attempt to fight legal change).

45. See Kyle D. Logue, Tax Transitions, Opportunistic Retroactivity, and the Benefits of Government Precommitment, 94 Mich. L. REV. 1129, 1138-43 (1996) (arguing that legal change will become more challenging, or even impossible, in certain settings without transition relief); Jonathan Masur, Judicial Deference and the Credibility of Agency Commitments, 60 VAND. L. Rev. 1021, 1041-47 (2007) (same).

46. See Nash \& Revesz, supra note 10, at 1725-27 (discussing timing issues related to the Clean Air Act).

47. Carbon Pollution Emission Guidelines for Existing Stationary Sources: Electric Utility Generating Units, 80 Fed. Reg. 64,662 (Oct. 23, 2015) (to be codified at 40 C.F.R. pt. $60)$.

48. See Noah Kaufman \& Eleanor Krause, The Economic Impacts of the Clean Power Plan: How Studies of the Same Regulation Can Produce Such Different Results (World Res. Inst. Working Paper, 2017), https://www.wri.org/research/economic-impacts-clean-powerplan-how-studies-same-regulation-can-produce-such-different [https://perma.cc/5TQDGWYZ].

49. Repeal of the Clean Power Plan; Emission Guidelines for Greenhouse Gas Emissions from Existing Electric Utility Generating Units; Revisions to Emission Guidelines Implementing Regulations, 84 Fed. Reg. 32,520, 32,521 (July 8, 2019) (to be codified at 40 C.F.R. pt. 60).

50. The Supreme Court recently granted certiorari in a set of cases that may determine the viability of the Clean Power Plan. See Am. Lung. Assoc. v. EPA, 985 F.3d 914 (D.C. Cir. 2021), cert. granted sub nom. West Virginia v. EPA, 142 S. Ct. 420 (2021) (Nos. 20-1530, 20-1531, 20-1778, 20-1780). 
the Green New Deal were to become law, that would cause demand for wind turbines to spike. ${ }^{51}$

For Wind Co. the decision is fraught. If Wind Co. were to increase its operations, and demand does not rise sufficiently, the new facilities it constructed would be economically worthless, and the firm could go out of business. On the other hand, if Wind Co. does not increase production sufficiently, and passage of the Green New Deal or other highly protective climate rules causes demand for wind turbines to spike, Wind Co.—and, critically, all other wind companies like it — might not be able to meet the rising demand. This could lead to significant delays in the rollout of clean energy, with concomitant harm to the environment. ${ }^{52}$ It is not good enough for Wind Co. to estimate that there will "likely" be greenhouse gas regulation "of some type." It needs to know with some level of precision what form that regulation will take in order to anticipate future demand. Accurate predictive information about future regulatory action is thus essential to Wind Co.'s ability to take efficient, socially beneficial actions.

Yet this type of information is devilishly difficult to acquire for three related reasons. First, major statutes and regulations are largely idiosyncratic events. The fact that the 101st Congress passed the Clean Air Act Amendments of 1990 provides little information regarding whether the 117th Congress is likely to pass the Green New Deal. ${ }^{53}$ The dissimilarities between the two situations vastly outweigh the similarities. The number of overall events - the major statutes and regulations themselves - is also relatively low. ${ }^{54}$ Consequently, firms cannot engage in the type of large- $N$ data analysis that insurance companies use to price automobile or medical insurance.

Second, relevant information is widely dispersed, with multiple actors likely holding bits and pieces of it. ${ }^{55}$ With respect to potential regulation, some private party might have a sense of the EPA Administrator's views; another party might know what the Director of the White House Office of Management and Budget or the President's Chief of Staff would advise; a third might have a sense of the President's intentions; and so forth. ${ }^{56}$ The number of relevant actors is even much higher when

51. See H.R. 109, 116th Cong. (2019), https://www.congress.gov/bill/116thcongress/house-resolution/109/text [https:/perma.cc/EJK5-MVC3]; Lisa Friedman, What Is the Green New Deal? A Climate Proposal, Explained, N.Y. TiMES (Feb. 21, 2019), https:/www.nytimes.com/2019/02/21/climate/green-new-deal-questions-answers.html [https://perma.cc/CE8U-6645].

52. Cf. What Exactly Are 'Shovel-Ready' Projects?, GloBALFIELDS InSIGHT (June 2020), https://www.globalfields.co.uk/insights/what-exactly-are-shovel-ready-projects

[https://perma.cc/C2U2-RVL3] (noting that a deficit of infrastructure projects that are ready to be brought online can hamper economic recovery and stimulus efforts).

53. Masur \& Nash, supra note 9, at 428-35 (explaining the difficulties of pricing regulatory insurance due to the idiosyncratic nature of government action).

54. Id. at 432 .

55. See, e.g., George J. Stigler, The Theory of Economic Regulation, 2 BELl J. Econ. \& MGMT. SCI. 3, 7-8 (1971) (noting that the only actors with an incentive to gather information about regulation are those whose industries are affected); see also THOMAS O. MCGARITY, Reinventing Rationality: The Role of Regulatory ANAlysis in the Federal BUREAUCRACY 91 (1991).

56. See Thomas H. Hammond \& Jack H. Knott, Who Controls the Bureaucracy?: 
it comes to statutes. ${ }^{57}$ Predictive regulatory information thus involves an assembly problem: how can these dispersed pieces of information be aggregated into a comprehensive whole?

Third, predictive regulatory information is a public good and thus likely to be underproduced ${ }^{58}$ Like a public park, or a new scientific discovery, this type of information is valuable to many private parties ${ }^{59}$ However, the private party that unearths the information has no easy means of capturing all or even some of that value. ${ }^{60}$ This dampens the incentives to acquire such information in the first place. For instance, suppose that Wind Co. learns that President Biden's chief of staff favors enacting the Green New Deal into law. That information is valuable to Wind Co., and it is valuable to many other firms and private actors as well. Wind Co. has no obvious mechanism for internalizing the global benefits of this information. It thus has suboptimal incentives to work at uncovering or producing such information, and basically no incentive to disseminate the information publicly, even if it manages to acquire it. ${ }^{61}$

The upshot of these concerns is that much less predictive regulatory information will be generated and disseminated than would be socially optimal. ${ }^{62}$ Private actors will be forced to operate in the dark and will make unnecessarily wasteful decisions as a result. Without some type of intervention, either from the private or public sector,

Presidential Power, Congressional Dominance, Legal Constraints, and Bureaucratic Autonomy in a Model of Multi-Institutional Policy Making, 12 J.L. ECon. \& OrG. 119, 126 (1996) (noting that the de-centralized nature of administrative power makes it unlikely that any one actor, including the agency itself, has control over it); see also Robert G. Chambers \& John Quiggin, Non-Point-Source Pollution Regulation as a Multi-Task Principal-Agent Problem, 59 J. Pub. ECon. 95 (1996); Eric Biber, Too Many Things to Do: How to Deal with the Dysfunctions of Multiple-Goal Agencies, 33 HARV. ENV'T L. REV. 1 (2009).

57. See, e.g., Aziz Z. Huq, Does the Logic of Collective Action Explain Federalism Doctrine?, 66 StAn. L. Rev. 217 (2014); see also Norton E. Long, Power and Administration, 9 Pub. Admin. Rev. 257, 259 (1949) ("Even the subject matter of committees of Congress function in the shadow of agency permanency.").

58. See Paul A. Samuelson, The Pure Theory of Public Expenditure, 36 REv. Econ. \& Stat. 387 (1954); see also Bradley C. Karkkainen, Information-Forcing Environmental Regulation, 33 Fla. St. U. L. Rev. 861, 866 (2006) ("Much like contract penalty default rules, regulatory penalty defaults can be both information-forcing and 'action-forcing ....'").

59. See James M. Buchanan, Public Goods in Theory and Practice: A Note on the Minasian-Samuelson Discussion, 10 J.L. \& Econ. 193, 194 (1967); see also Dana Dalrymple, Scientific Knowledge as a Global Public Good: Contributions to Innovation and the Economy, in The Role of Scientific and Technical Data and Information in the Public Domain: Proceedings of A Symposium 35 (Julie M. Esanu \& Paul F. Uhlir eds., 2003), https://www.nap.edu/read/10785/chapter/6 [https://perma.cc/DN2S-LB9T].

60. Cf. Richard A. Posner, Intellectual Property: The Law and Economics Approach, 19 J. ECON. PERSP. 57, 65 (2005).

61. Id. at 66; see also Golan v. Holder, 565 U.S. 302, 344-45 (2017) (Breyer, J., dissenting) ("In order ' $[\mathrm{t}] \mathrm{o}$ promote the Progress of Science' (by which term the Founders meant 'learning' or 'knowledge'), the Constitution's Copyright Clause grants Congress the power to 'secur[e] for limited Times to Authors... the exclusive Right to their... Writings." (quoting U.S. Const. art. I, § 8, cl. 8)).

62. See Buchanan, supra note 59; see also Samuelson, supra note 58. 
information that could be put to valuable use will lie fallow. The next two Parts consider a range of potential solutions.

\section{MARKET-BASED SOLUtions TO THE PROBlEM OF REgUlAtory INFORMATION}

The preceding Part illustrated the social value of predictive regulatory information. The question then arises: what mechanisms can successfully generate such predictive information? In this Part, we consider market-based mechanisms for promoting the production of regulatory information and hedging risk. We begin with a market-based mechanism that currently enjoys widespread popularity among scholars and some policymakers: prediction markets. We explore how prediction markets are supposed to work and examine whether they can be expected to function successfully to generate predictive information about future government action. We then consider whether the stock market itself could perform such functions. Finally, we consider the possibility that predictive technology could fill this role. Our conclusions regarding all these possibilities are, unfortunately, pessimistic.

\section{A. The Promise and Pitfalls of Prediction Markets}

Prediction markets are a means by which societal actors can gain access to accurate information about the future. ${ }^{63}$ The intuition behind prediction markets is straightforward: markets excel at assembling dispersed, privately held information by inducing participants to share various pieces of information. ${ }^{64}$

The operation of a prediction market is also straightforward. ${ }^{65}$ Michael Abramowicz explains:

The information market's sponsor issues one or more securities and provides some form of prospectus specifying how each security will eventually be redeemed. Each security's payout will be some function of a number or numbers that will become objectively verifiable by the time of redemption. The sponsor sells securities to those who wish to participate in the market, and participants subsequently can trade securities with one another. Typically, these trades are facilitated by a market maker who matches those wishing to buy and sell a particular security; trades occur when someone is willing to buy at a price greater than or equal to the price at which someone else is willing to sell, that is, when the largest bid price is greater than or equal to the largest ask

63. For a taxonomy of types of prediction markets, see Justin Wolfers \& Eric Zitzewitz, Prediction Markets, 18 J. ECON. PerSP. 107, 109-10 (2004); Michael Abramowicz, Information Markets, Administrative Decisionmaking, and Predictive Cost-Benefit Analysis, 71 U. CHI. L. Rev. 933, 948-49 (2004).

64. See, e.g., Shi-Ling Hsu, A Prediction Market for Climate Outcomes, 83 U. Colo. L. REV. 179, 201 (2011) ("[M]arkets have always been very effective in knitting together disparate pieces of information and transmitting them in the pithy singularity of a price.”); Cass R. Sunstein, Infotopia: How Many Minds Produce Knowledge 197 (2006) (to similar effect).

65. See Abramowicz, supra note 63, at 943 (describing the "basic information market's operation" as "simple"). 
price. The prices at which these transactions occur, as well as the bid and ask prices, reflect market predictions of the eventual payout and thus of the number or numbers on which that payout is based. ${ }^{66}$

Commentators generally recognize the essential predictive power of prediction markets. ${ }^{67}$ Existing prediction markets have been used to generate predictions about economic indicators ${ }^{68}$ and real-world events such as the outcomes of elections. ${ }^{69}$ Commentators have advocated for the use of prediction markets to assess events (such as hurricanes and temperature rise) associated with climate change ${ }^{70}$ and particular corporate outcomes. ${ }^{71}$

Commentators have also considered the establishment of prediction markets for particular government actions. ${ }^{72}$ The predicate for a prediction market- dispersed privately held information about the future - is met. For example, in the context of a regulatory change, relevant information may be held by various government officials, private firms, lobbyists, and so forth. Prediction markets also help to solve the public goods problem by allowing actors to profit on the information they hold through trading on the market. And whether widely dispersed or not, such information is likely to be privately held - that is, not generally available to the public. The structure of these markets would be similar to existing prediction

66. Id. at $943-44$ (footnote omitted).

67. See Wolfers \& Zitzewitz, supra note 63, at 112-15; Abramowicz, supra note 63, at 950 ("Collectively, these data seem sufficient to establish that the markets' predictions were neither haphazard nor perfectly omniscient."); see also SUNSTEIN, supra note 64, at 113-15 (noting the accuracy even of prediction markets run by Google but not with real money).

Some commentators extol prediction markets not only for producing accurate information about the future but also for generating information in which the public may have greater confidence than information (even the same or similar information) generated by other sources, such as the government. See Michael P. Vandenbergh, Kaitlin Toner Raimi \& Jonathan M. Gilligan, Energy and Climate Change: A Climate Prediction Market, 61 UCLA L. REV. 1962, 1984 (2014) ("A climate prediction market could serve as a more formal way for scientific, political, and activist elites, as well as laypeople, to demonstrate their confidence in their own views in a way that risks their financial well-being if they are dishonest."); Hsu, supra note 64, at 200 ("There is an institution that, while currently suffering through a period of disapproval, is thought to be apolitical and may still be more confidence-inspiring than climate scientists: the market."). But see Cherie Metcalf \& Jonathan R. Nash, Institutions, Information, and Beliefs: Public Perception of Climate Change Information Provided by Government vs. the Market (unpublished working paper on file with the Indiana Law Journal) (presenting empirical evidence in tension with this assertion).

68. See Wolfers \& Zitzewitz, supra note 63, at 114.

69. See id. at 112.

70. See Hsu, supra note 64, at 218-27; Vandenbergh, Raimi \& Gilligan, supra note 67, at 1996-97; Gary M. Lucas, Jr. \& Felix Mormann, Betting on Climate Policy: Using Prediction Markets to Address Global Warming, 52 U.C. DAvis L. REV. 1429 (2019).

71. See Michael Abramowicz \& M. Todd Henderson, Prediction Markets for Corporate Governance, 82 Notre DAme L. REV. 1343, 1350-54 (2007).

72. See Masur \& Nash, supra note 9, at 428-35; Tom W. Bell, Government Prediction Markets: Why, Who, and How, 116 PENN. St. L. REV. 403 (2011); see also SunsteIn, supra note 64 , at 132 (suggesting the use of a prediction market to assess future federal budget deficits). 
markets ${ }^{73}$ the triggering event would be whether some government action is taken by some particular date. ${ }^{74}$

Yet, as an initial matter, the horizontal and vertical division of authority across governmental actors introduces challenges to creating a functioning prediction market for government actors. Should a prediction market be tied to whether a government action is taken by either legislation or regulation, ${ }^{75}$ or should it be tied to a particular lawmaking process? And should the triggering event be whether legal change is accomplished by either the federal government, any state government, or any local government, or should it instead be tied to a particular government?

On the one hand, the desire to minimize the risk of a thin market argues in favor of defining the relevant action broadly, without regard to which level of government effects it, or to which mode of lawmaking is used to effect it. Defining the government action across levels of government and lawmaking modes increases the number of prospective market participants who might hold relevant information about the likelihood of the government action coming to pass. At the same time, such a broad definition of government action might invite market manipulation: after all, a market participant with particular authority over one level of government-a setting perhaps especially likely with respect to local government action ${ }^{76}$ - could well force the triggering of the relevant event. The broad definition of government action would also impose pricing problems. For example, an individual with some relevant information about whether Congress will take action on climate change might not be sure how to assess the overall likelihood that the federal government will take action on climate change and therefore nevertheless refrain from entering

73. However, greater legal hurdles might attend prediction markets for government action. See Bell, supra note 72, at 417-25.

74. But see infra note 76 and accompanying text (describing different ways in which the relevant "government action" might be defined).

75. One could add legal change by judicial decision to the mix.

76. See Nadav Shoked, The New Local, 100 VA. L. Rev. 1323, 1387 (2014) (“To govern in ... a larger-scale realm[,] coalitions must be formed, and it is harder for one group to capture government. In a smaller arena, such as the micro-local one, broad coalitions are unnecessary and tyranny of one group is much more easily sustained." (footnotes omitted)); Matthew J. Parlow, Civic Republicanism, Public Choice Theory, and Neighborhood Councils: A New Model for Civic Engagement, 79 U. Colo. L. REv. 137, 152 (2008) ("[L]ack of civic engagement creates the preconditions for local governments that lack transparency and community oversight, are subject to greater incidence of capture, and produce illegitimate local government outputs."); Daniel R. Mandelker \& A. Dan Tarlock, Shifting the Presumption of Constitutionality in Land-Use Law, 24 URB. LAw. 1, 36 (1992) ("Capture theory was initially developed to explain why administrative agencies were unresponsive to new values, but can also be applied to local government politics."); William A. Fischel, Introduction: Utilitarian Balancing and Formalism in Takings, 88 CoLum. L. Rev. 1581, 1582 (1988) ("Local governments are more prone to majoritarianism than other levels of government because they usually lack the electoral diversity that comes with large land area and large population and because, as derivative governments, they also lack the other constitutional checks on the will of the majority, such as bicameral legislatures and separation of powers."). But see Einer Richard Elhauge, The Scope of Antitrust Process, 104 HARV. L. REV. 667, 722-23 n.270 (1991) ("Nor is it clear that state and local governments are more susceptible to capture than Congress."). 
the market. Similarly, an individual with some relevant information about whether the federal government will take action on climate change might not be sure how to assess the overall likelihood that any government - federal or state - will take action on climate change.

On the other hand, the desire to ensure that the prediction market functions effectively requires specifying with precision both the level of government that is acting and the mode of lawmaking by which the legal change is effected. After all, "[f]or a prediction market to work well, contracts must be clear, easily understood and easily adjudicated." 77 But such an approach would fragment the market into submarkets, each of which is more at risk of being a thin market. And these thin markets - perhaps especially those keyed to local government action ${ }^{78}$ - might be particularly susceptible to market manipulation. Another problem with this narrow approach to defining the relevant market is that action (or inaction) by one government actor sometimes prompts action by another government actor. ${ }^{79}$ Thus, an accurate prediction about one government actor's likely action may in any event have to take into account predictions about the likely actions (or inactions) of other government actors.

One might take the position that, at least with respect to the debate over level of government, there is a "correct" answer for many categories of government actions: focus on the federal government. Commentators have argued that companies that engage in a national market have a strong interest in effecting legal change at the federal level in order to secure uniform national standards. These national actors have a far easier time lobbying federal government actors than actors on subnational governmental units, and opposing lobbying forces face a difficult challenge in moving the relevant battleground back to the subnational level. Thus, as one might then expect, as national markets have increased, so too have lobbying efforts focused on the national government. ${ }^{80}$

But for many firms, state-level regulatory action will also be highly significantin some cases nearly as significant as national action. And in some areas of regulation, the states have been just as active as the federal government. Consider, for example, the challenges presented by climate change. Given the global nature of the problem, ${ }^{81}$ one might think that the federal government would be the one to take action on climate change. Yet it has in fact been state and local governments that

77. Wolfers \& Zitzewitz, supra note 63 , at 120.

78. See supra note 76 and accompanying text.

79. See Ann E. Carlson, Iterative Federalism and Climate Change, 103 Nw. U. L. REv. 1097, 1107-60 (2009).

80. See Samuel Issacharoff \& Catherine M. Sharkey, Backdoor Federalization, 53 UCLA L. ReV. 1353, 1360-64 (2006); Jonathan Remy Nash, The Illusion of Devolution in Environmental Law, 38 URB. LAW. 1003, 1012 (2006).

81. See, e.g., Jonathan Remy Nash \& Richard L. Revesz, Markets and Geography: Designing Marketable Permit Schemes to Control Local and Regional Pollutants, 28 ECOLOGY L.Q. 569, 576 (2001) (describing greenhouse gases as a "global pollutant"). 
have taken the lead. ${ }^{82}$ More generally, it is open to debate which level of government is more competent to address various regulatory challenges. ${ }^{83}$

Even if these organizational issues could be overcome, it remains doubtful that regulatory prediction markets would function effectively and generate reliable prices. There are at least three critical obstacles to a prediction market for government action setting an accurate price, and thus generating a reliable prediction: the questionable ability of prospective market participants to be able to formulate an accurate estimate of the likelihood of the event in question, the problem of thin markets, and the problem of market manipulation. Each of these obstacles is exacerbated, moreover, by the various levels of government and the means by which any particular government can implement legal change.

First, would-be market participants may find it difficult to predict the likelihood of a particular government action with accuracy. Even someone with some relevant information may find that information too insubstantial a base on which to formulate a probabilistic assessment. Moreover, prior experience with government action may not provide a good guide for how future government actions will (or will not) proceed. ${ }^{84}$

Second, a thin market - that is, a market with an insufficient number of participants - runs the risk of mispricing: " $[\mathrm{t}]$ he central problem of thin information markets is that information markets rely on voluntary transactions to assess market consensus, but transactions will not occur with sufficient frequency to reach an accurate consensus under certain conditions." 85 And a market for government action might well involve a relatively small number of individuals with relevant knowledge. Indeed, there are legal concerns with government employees-who possess perhaps the greatest insight on future government action — entering such markets. ${ }^{86}$

82. See, e.g., Judith Resnik, Joshua Civin \& Joseph Frueh, Ratifying Kyoto at the Local Level: Sovereigntism, Federalism, and Translocal Organizations of Government Actors (TOGAs), 50 ARIZ. L. REV. 709 (2008); Kevin L. Doran, U.S. Sub-Federal Climate Change Initiatives: An Irrational Means to a Rational End?, 26 VA. ENV'T L.J. 189, 190 (2008); Thomas Forman, The Role of Cities and States in Combating Climate Change, GEO. ENV'T L. REV. (Jan. 31, 2017), https://gielr.wordpress.com/2017/01/31/the-role-of-cities-and-states-incombating-climate-change/ [https://perma.cc/3LTR-9WZR]; see also Katrina M. Wyman \& Danielle Spiegel-Feld, The Urban Environmental Renaissance, 108 CALIF. L. REV. 305 (2020).

83. Cf. William W. Buzbee, The Regulatory Fragmentation Continuum, Westway and the Challenges of Regional Growth, 21 J.L. \& PoL. 323, 351 (2005) (noting that academic commentary "tends to see as desirable the allocation of regulatory authority to either federal, state or local regulators, depending on the analyst's particular weighing of constitutional values and empirical predictions about federal, state and local incentives and areas of competence").

84. See Masur \& Nash, supra note 9, at 431-32; see also SUNSTEIN, supra note 64, at 143 (arguing that some government actions involve "judgments of value, not merely of fact, and no information market can make judgments of value").

85. Abramowicz, supra note 63, at 958; see SUNSTEIN, supra note 64, at 144 ("When the relevant groups are small, effective markets may be impossible to create simply because there are not enough investors.").

86. See Masur \& Nash, supra note 9 at 435. 
Third, the possibility that a small number of individuals could dominate market transactions and thus manipulate the market and its pricing function is a real concern. ${ }^{87}$ And that concern looms larger in thin markets. Moreover, in the context of prediction markets for government action, it is possible for manipulation to arise in another way: those with the power to affect government action (lobbyists and government actors) could enter the market and then take action to maximize the value of their market position. ${ }^{88}$

The risk of manipulation is particularly high if prediction markets are used to set prices in other markets, such as in a private insurance market. ${ }^{89}$ If a prediction market — even a very thin one — developed around a regulatory risk, insurers might try to use the prediction generated by that market to price their private insurance. The prediction market need not have sufficient volume or liquidity to enable hedging; it only need be relatively accurate, and private insurers could then supply the necessary financial volume. But this is precisely the circumstance under which manipulation would become attractive and profitable: manipulation of a low-volume market (the prediction market), at relatively low cost, would substantially affect prices on a much higher-volume market (the private insurance market), where far more money is at stake. ${ }^{90}$ Insurers could manipulate the prediction market to drive up the price of the insurance they are selling, making it seem as if the actuarially fair price is much higher than it really is. Alternatively, purchasers of insurance could manipulate the market to drive down the price of the insurance they plan to purchase. ${ }^{91}$ Either way, the prediction market will not be a reliable indicator of the fair price of regulatory insurance. Insurance companies and insurance purchasers will be reluctant to rely on it. A prediction market cannot be counted on to reliably generate a market for privatesector insurance.

\section{B. Equity Markets as Hedge}

The primary value of prediction markets is that they facilitate the aggregation of information. Private parties who possess inside information have an incentive to "share" it by buying and selling on the prediction market; the incentive is created by the fact that private parties can make money by trading on the information they possess. At the same time, part of the motivation for prediction markets is that such

87. See Abramowicz, supra note 63, at 972-76; SUnSTEIN, supra note 64, at 137-38.

88. See Masur \& Nash, supra note 9, at 432 . While limits on lobbying might address some of these concerns, such limits might raise separate constitutional concerns. See, e.g., Maggie McKinley, Lobbying and the Petition Clause, 68 Stan. L. Rev. 1131, 1156-204 (2016); Andrew P. Thomas, Easing the Pressure on Pressure Groups: Toward a Constitutional Right to Lobby, 16 HARV. J.L. \& PuB. POL'y 149, 151-91 (1993).

89. See Masur \& Nash, supra note 9, at 433-35 (suggesting that prediction markets might be used in this fashion).

90. See Abramowicz, supra note 63, at 977 (describing the problems related to manipulation of shallow markets when those markets have larger consequences).

91. See SunsteIn, supra note 64, at 137-38 (noting this and related problems with this type of prediction market). Of course, it is possible that these two effects could offset. But if they did so, it would be entirely fortuitous, not something that could be planned or relied upon. This means that the market is not likely to be priced properly. 
markets could themselves be used by private parties to hedge risk, whether or not those private parties possess any information of their own. As we explained above, we are not optimistic that prediction markets will be able to perform either of these functions effectively.

Yet if prediction markets will not provide effective means of hedging regulatory risk, perhaps firms could use the regular capital markets instead. After all, two of the principal problems with prediction markets as hedging devices are the thinness of those markets (that is, the lack of liquidity) and the concomitant fear that the markets could be manipulated. The equity markets do not share either of these flaws. They are generally highly liquid, with enormous volumes of major stocks being traded each day. ${ }^{92}$ In part because of this high level of liquidity, they are very difficult to manipulate. ${ }^{93}$ They are also protected by securities laws, which make market manipulation unpalatable to all but the most unscrupulous traders. ${ }^{94}$

Of course, hedging via the equity markets would not perform the primary function we envisioned for prediction markets: it would not lead to the public aggregation of information in a way that would allow all parties - informed or uninformed - to hedge risk more effectively. Hedging through the public equity markets would only be valuable for those firms that already possessed enough information to make an accurate regulatory prediction on their own. Accordingly, this type of hedging should be viewed as second-best to the other types of solutions we explore through this Article. Still, for firms possessing actionable information, it would be better than nothing.

To fix intuitions, consider our aforementioned hypothetical wind turbine firm, Wind Co. Suppose that this firm decides to hedge against the possibility that the Green New Deal will not be passed by buying shares of a coal company. The theory is that if the Green New Deal does not become law, this will raise the value of the coal company just as it harms demand for the firm's wind turbines. ${ }^{95}$ The problem is that the passage (or not) of the Green New Deal is not the only thing that could affect the fortunes of this coal company. For instance, advances in fracking technology could make natural gas much cheaper, which would diminish the value of both the coal company and the wind turbine firm. ${ }^{96}$ To hedge this risk, perhaps the wind turbine firm would need to purchase shares in natural gas companies as well.

92. Kristin N. Johnson, Regulating Innovation: High Frequency Trading in Dark Pools, 42 J. CoRP. L. 833, 839-41 (2017); Jennifer Victoria Christine Dean, Paradigm Shifts \& Unintended Consequences: The Death of the Specialist, the Rise of High Frequency Trading, $\&$ the Problem of Duty-Free Liquidity in Equity Markets, 8 FIU L. Rev. 217, 236 (2012).

93. Charles R. Korsmo, Mismatch: The Misuse of Market Efficiency in Market Manipulation Class Actions, 52 WM. \& MARY L. REV. 1111, 1143-47 (2011); Richard E. Ramirez, Falling Short: Has the SEC's Quest to Control Market Manipulation and Abusive Short-Selling Come to an End, Or Has It Really Just Begun?, 2 U. P.R. Bus. L.J. 76, 83 (2011).

94. See Merritt B. Fox, Lawrence R. Glosten \& Gabriel V. Rauterberg, Stock Market Manipulation and Its Regulation, 35 YALE J. ON RegUL. 67, 69-70 (2018).

95. See Michael Mehling, A New Direction for US Climate Policy: Assessing the First 100 Days of Donald Trump's Presidency, 11 CARBon \& Climate L. Rev. 3, 19 (2017).

96. Thomas W. Merrill, Four Questions About Fracking, 63 CASE W. RSRV. L. REV. 971, 974, 981 (2013). 
But the financial fortunes of natural gas firms could be affected by other, separate events. For instance, suppose that regulators ease the regulatory approval process for new nuclear plants. This would make nuclear power cheaper in comparison to other energy sources, thus harming natural gas, coal, and wind turbine firms. ${ }^{97}$ Perhaps the wind turbine firm should purchase shares in nuclear power companies as well? At this point, however, the wind turbine firm would have enormous exposure to the energy sector. Some event that decreased demand for energy generally - a global pandemic, for instance-would then have a multiplicative effect on the firm's fortunes. ${ }^{98}$ What is more, the wind turbine firm would have in effect hedged its own risk by taking long positions in all of its competitors. If this firm achieves its own technological breakthrough — dramatically improving wind turbine technology—its gains will be largely offset by losses in the stocks of these other firms. This is not an effective way to hedge a discrete regulatory risk.

The more general point is that major corporate firms contain multitudes. There are hundreds (or thousands) of separate events that could cause the fortunes of a given firm, or even an entire sector, to rise or fall. ${ }^{99}$ Regulatory or legislative action is just one (or several) of those potential events. For that reason, it will be impossible to find a stock or basket of stocks that effectively hedge a firm's exposure to regulatory risk without exposing that firm to many additional risks, risks that it has no interest in taking on. The process of hedging those risks, and then the risks that are created by those hedges, and then the risks created by those hedges, and so forth, will lead firms into a spiral of infinite regress from which there is no easy escape. This is simply not a realistic solution for a firm seeking to hedge regulatory risk.

\section{Machine Learning and Predictive Technologies}

To this point, we have assumed (if implicitly) that actors' ability to predict future government action, given some set quantity of current information, remains constant. But recent years have seen major advances in the use of technology to predict the legal future. ${ }^{100}$ We readily concede that better predictive technology facilitates better predictions about what actions government might take and that this is a good thing. That said, we are dubious that improvements in predictive technology alone will

97. See Justin Gundlach, What's the Cost of a New Nuclear Power Plant? The Answer's Gonna Cost You: A Risk-Based Approach to Estimating the Cost of New Nuclear Plants, 18 N.Y.U. ENV'T L.J. 600, 641-53 (2011).

98. See William C. Smith, Save Domestic Oil, Inc. 's Crude Oil Market Dumping Petition: Domestic and International Political Considerations, 8 TULSA J. COMPAR. \& INT'L L. 147 (2000). On the other hand, a war in the Middle East could dramatically increase oil prices and have the opposite effect. See Tracey A. Beecher, An Examination of the U.S.-Iraqi War's Effect on the Global Oil Trade and the Global Economy, 13 CuRRENTS. 105, 105-06 (2003).

99. See Travis Miller, The Evolving Regulations and Liabilities Entwined in Corporate Social Responsibility, 46 Tex. ENV'T L.J. 219, 220-21 (2017); William Magnuson, Unilateral Corporate Regulation, 17 CHI. J. INT'L L. 521, 540-41 (2017).

100. See, e.g., Daniel Martin Katz, Quantitative Legal Prediction-or-How I Learned to Stop Worrying and Start Preparing for the Data-Driven Future of the Legal Services Industry, 62 EMORY L.J. 909, 913-49 (2013). 
provide a full enough solution for private actors looking to hedge against future government action.

First, predictive technology can only generate predictions as good as the available data points. ${ }^{101}$ Thus, the upside to predictive technology is limited by the available data.

Second, and relatedly, predictive technology does nothing to dislodge privately held predictive information. Thus, while predictive technology may excel at aggregating and interpreting dispersed information, it does nothing to improve the set of available information. And it cannot aggregate and interpret that to which it does not have access. To put the first two points another way, no matter how much technological advances improve matters, predictive technology could presumably do even better with the disclosure of more predictive information.

Third, even beyond the access-to-information problem, predictive technology still faces the broader obstacle that the generation of law is an example of a complex adaptive system. Complex adaptive systems are the subject of study of complexity science. ${ }^{102}$ They are systems "in which large networks of components with no central control and simple rules of operation give rise to complex collective behavior, sophisticated information processing, and adaptation via learning or evolution."103

Commentators have readily categorized the law at the macro level as a complex adaptive system. ${ }^{104}$ But a moment's reflection confirms that the generation of law exhibits features of a complex adaptive system even at the micro level. ${ }^{105}$ Indeed,

101. See, e.g., Michael Mills, Using AI in Law Practice: It's Practical Now, 42 LAw PraC. 48, 50 (2016) ("Good predictions depend on good data...."); Andrew Guthrie Ferguson, Policing Predictive Policing, 94 Wash. U. L. Rev. 1109, 1145 (2017) ("Predictive technologies require data....").

102. See, e.g., Jonathan Remy Nash, J.B. Ruhl \& James Salzman, The Production Function of the Regulatory State: How Much Do Agency Budgets Matter?, 102 MinN. L. Rev. 695, 750 (2017).

103. Melanie Mitchell, Complexity: A Guided Tour 13 (2009). Complex systems can be highly adaptive (like an ecosystem or the law) or nonadaptive (like a hurricane). See id.

104. See J.B. Ruhl \& Daniel Martin Katz, Measuring, Monitoring, and Managing Legal Complexity, 101 Iowa L. REv. 191, 201-07 (2015); J. B. Ruhl, Daniel Martin Katz \& Michael J. Bommarito II, Harnessing Legal Complexity: Bring Tools of Complexity Science to Bear on Improving Law, SCIENCE, Mar. 31, 2017, at 1377, 1377.

105. To be sure, scholars have established machine learning as a viable way to predict legal outcomes in certain contexts. See, e.g., Benjamin Alarie, Anthony Niblett \& Albert H. Yoon, Using Machine Learning to Predict Outcomes in Tax Law, 58 CANADIAn Bus. L.J. 231 (2016) (addressing predictions as to whether an individual is an employee or an independent contractor for tax purposes). But these efforts assume that the governing law remains staticsomething our project most definitively does not assume. Such efforts are focused on law application, not law generation.

At the same time, progress has been made on certain aspects of law generation. For example, recent research suggests an ability to predict which among a collection of congressional bills will become law based upon the text analysis of the bills (a feature, we note, that is not based on privately held predictive information, as such). See John J. Nay, Predicting and Understanding Law-Making with Word Vectors and an Ensemble Model, 12 PLOS ONE May 10, 2017, at 1, https://journals.plos.org/ plosone/article?id=10.1371/journal.pone.0176999 [https://perma.cc/M6B7-CTV6]. But, 
some of the features we have noted in previous Subparts are features of this categorization. Action by one branch of government can influence actions by other branches. ${ }^{106}$ Moreover, private actions can also affect the actions of the government; indeed, private actors' predictions about legal change can prompt those actors to engage in lobbying, which in turn can change the validity of those predictions. ${ }^{107}$

promising though such research may be, the fact remains that it addresses only a small subset of the law-generation process - especially if we expand our desire for prediction beyond a single branch, and a single level, of government.

Professors Anthony Casey and Anthony Niblett posit that predictive technology will eventually advance to the point that laws will update automatically as the state of the world changes. See Anthony J. Casey \& Anthony Niblett, Self-Driving Laws, 66 U. TORONTO L.J. 429, 433 (2016) ("Micro-directives, based on ... predictive algorithms, will update automatically as the state of the world changes. Laws will update automatically."). But this rather utopian view of the future rests, if somewhat implicitly, on perfect (or close to perfect) information flow between regulators and the regulated. See, e.g., id. at 434 ("[A]dvancements in prediction and communication will be reinforced by other technological advancements in fact gathering and verification. As machines get better at gathering and verifying facts, more and more data will be generated and analyzed."); $i d$. at 433 ("Even though the micro-directives are automated and update in real time, human lawmakers will be required to set the broad objectives of the law."). Presumably, however, societal actors must have foreknowledge of those broad objectives in order to predict the micro-directives accurately. Their vision also rests uncomfortably with the notion that at least some areas of law are indefeasible, that is, they are not reducible to pure, finite logic expression. See Jonathan R. Nash, Legal Defeasibility in Context and the Emergence of Substantial Indefeasibility, in THE LOGIC OF Legal Requirements: Essays on Defeasibility 377 (Jordi Ferrer Beltrán \& Giovanni Battista Ratti eds., 2012), for discussion.

106. See supra note 76 and accompanying text. Consider as well President Donald Trump's comments that lower court decisions enjoining the administration from ending the "Deferred Action for Child Arrivals" (DACA) immigration program, which began under President Barack Obama, precluded the administration from reaching a deal with Democrats to statutorily ensconce DACA in return for border wall funding (which in turn contributed to the year-end partial government shutdown). See Melissa Quinn, Trump Says Court Ruling Sank DACA-Wall Deal, WASH. EXAMINER (Dec. 27, 2018), https://www.washingtonexaminer.com/news/trump-says-court-ruling-sank-daca-wall-deal [https://perma.cc/2B6H-2ENZ]. President Trump also indicated that no such negotiations could happen until the Supreme Court ultimately resolved the issue. See Sheryl Gay Stolberg \& Michael Tackett, Trump Suggests Government Shutdown Could Last for 'Months or Even Years,' N.Y. Times (Jan. 5, 2019), https://www.nytimes.com/2019/01/04/us/politics/ democrats-trump-meeting-government-shutdown.html [https://perma.cc/7RP6-QJMZ] ("Mr. Trump made clear that he did not want to address the DACA issue - which is now the subject of several lawsuits that are working their way through the federal courts - until the Supreme Court renders a final decision on whether Mr. Trump's order to rescind the program can stand.").

107. See supra note 88 and accompanying text (discussing how private actors' predictions about legal change can prompt those actors to engage in lobbying, which in turn can change the validity of those predictions); see also Michael Abramowicz, Predictive Decisionmaking, 92 VA. L. ReV. 69, 101 (2006) ("A predictive decisionmaking regime must consider not only the innate ability of predictors, but also how they will make predictions when they realize that these predictions will have policy effects."). 
Finally, the number and variety of potential actors for which predictions would be sought increases the obstacles further still. Researchers using textual analysis have discovered substantial differences among the word choices and arrangements used by the President, the House of Representatives, the Senate, and the Supreme Court. ${ }^{108}$ Any attempt to use machine learning to generate a "unified" prediction across political bodies would have to factor in this variation in word choice - in addition to other variations. The challenges to developing programs that can incorporate this complexity are thus clearly substantial.

In sum, while advances in predictive technology will doubtless help societal actors make better predictions about future government action, the improvement in those predictions will remain constrained by both limited information and the law's status as a complex adaptive system.

\section{The Role of Government IN FACILITATING the Flow of Predictive INFORMATION}

If private markets and private technology will not be effective in promoting the production and dissemination of regulatory information, then perhaps there is a role for government in doing so. In this Part, we discuss three potential options. One possibility is for the government to facilitate private actors' ability to predict future government action by voluntarily subjecting its own decision-making processes to greater transparency. The use of transparency toward this end has promise, but also gives rise to a risk that government decision-making processes will become less efficient and generate worse work products - that is, that the law itself will be worse.

The second possibility would be for the government to create property rights in regulatory information. These property rights would function like standard intellectual property (IP) and would serve the same purpose: to create incentives for the production and dissemination of regulatory information by allowing its creators to internalize the benefits of producing such information. However, we believe that there are conceptual problems with this approach that policymakers will not be able to overcome.

The third possibility is what we term "prediction-forcing regulation."109 Prediction-forcing regulation is government regulation that obligates regulated entities to disclose whatever information they might have regarding the likelihood of future government action. ${ }^{110}$ In other words, it is regulation whose goal is to generate

108. See John J. Nay, Gov2Vec: Learning Distributed Representations of Institutions and Their Legal Text, in Proceedings of the Empirical Methods in Natural Language Processing Workshop on Natural language Processing and Computational Social SCIENCE 49 (2016).

109. Prediction-forcing regulation is similar to other regulatory forms that encourage societal actors to act with foresight with respect to the future. See Jonathan B. Wiener, The Diffusion of Regulatory Oversight, in The Globalization of Cost-Benefit ANAlysis in Environmental Policy 123, 133-36 (Michael A. Livermore \& Richard L. Revesz eds., 2013); Jonathan B. Wiener \& Daniel L. Ribeiro, Impact Assessment: Diffusion and Integration, in COMPARATIVE LAW AND REgulation: Understanding THE GlOBAL Regulatory Process 159, 161-64 (Francesca Bignami \& David Zaring eds., 2016).

110. One might take the position that prediction-forcing regulation is a subspecies of 
information about future regulation. We derive the terminology from the monikers "technology-forcing regulation"111 and "information-forcing regulation," 112 both commonly used in the context of environmental regulation. Prediction-forcing regulation is no better than a second-best solution, if that, and the very fact that we are forced to consider it should serve to highlight the largely intractable nature of the information problem we describe here. Nonetheless, if better solutions are not forthcoming, it is worth at least considering this one.

\section{A. Heightened Government Transparency}

Perhaps the most effective mechanism for the government to facilitate private predictions about future government action would be for organs of the government simply to provide more extensive information about their own operations. Greater government transparency would provide private actors with more information on which to base such predictions. Indeed, some government actors and actions are already subject to considerable requirements of transparency. Consider so-called sunshine laws, which require disclosure of certain government actions and individuals involved with those actions, ${ }^{113}$ and how administrative law often calls for transparency in the regulatory process. ${ }^{114}$ A government could decide to increase transparency in decision-making in order to enhance societal actors' ability to predict future government action. Moreover, increased government transparency could

information-forcing regulation. Prediction-forcing regulation, after all, mandates the production of a form of information. And both types of regulation call for disgorgement of privately held information for some public benefit. We believe that the better approach is to consider prediction-forcing regulation as distinct from (albeit related to) information-forcing regulation. Information-forcing regulation calls for public dissemination of information about the regulated entity. In contrast, prediction-forcing regulation requires public dissemination held by the regulated entity, but about some future possible government action. Informationforcing regulation allows the market better to assess the status, and value, of the regulated entity; prediction-forcing regulation allows the market, and the public, to better assess the likelihood of future government action.

111. Technology-forcing regulation is regulation that may call upon regulated entities to develop technologies that are not yet in existence. For example, the Clean Air Act authorizes the EPA to introduce requirements applicable to manufacturers of mobile sources - that is, generally, motor vehicles - that may require those manufacturers to develop technologies that do not yet exist. See, e.g., Int'l Harvester Co. v. Ruckelshaus, 478 F.2d 615 (D.C. Cir. 1973).

112. Information-forcing regulation is regulation that does not require regulated entities to undertake any substantive changes to their production processes or products; it simply calls upon the entities to disclose certain information. For example, the Emergency Planning and Community Right-to-Know Act of 1986, 42 U.S.C. $\S \S 11001-11050$, requires companies to disclose to the EPA when they have released toxic chemicals. From these reports, the EPA assembles the toxic release inventory.

113. See generally Teresa Dale Pupillo, The Changing Weather Forecast: Government in the Sunshine in the 1990s - An Analysis of State Sunshine Laws, 71 WASH. U. L.Q. 1165 (1993) (cataloging state "sunshine laws" that provide for open government and greater public information on legislative and regulatory processes).

114. See, e.g., 5 U.S.C. §553(b)-(d) (requiring notice to the public and an opportunity for public participation in the federal rulemaking process). 
render other approaches to facilitating prediction more effective; for example, increased transparency could aid in the development of functioning insurance markets. ${ }^{115}$

But greater government transparency is not a panacea. First, any effort by a government to increase transparency will almost inevitably leave sizeable blind spots. It is simply implausible that any government would require transparency in all modes of government decision-making. ${ }^{116}$ Second, remaining areas of opacity are likely to produce "leakage," that is, inefficient efforts by government actors to recast their actions in a way that minimizes transparency requirements. For instance, imagine a statute requiring that all official meetings held within the EPA be recorded, with the recordings posted on the EPA website. At first glance, it would seem as though such a law would dramatically increase the volume of information available to private parties. In truth, however, the agency would probably just move the relevant information "off-book." Discussions that the EPA preferred to remain private would no longer take place in official "meetings" - instead, the agency would rely more heavily on informal conversations or other methods of communication that were not subject to the law. More generally, lawmakers would expend effort to promulgate laws outside the scope of transparency requirements. ${ }^{17}$ Such efforts would frustrate the purpose of the transparency laws while simultaneously resulting in considerable inefficiencies. ${ }^{118}$

Third, no single transparency rule or set of rules would solve the problem. Of relevance once again is the division of lawmaking authority across levels of government. Any individual government is free to increase the transparency of its own actions. However, even the 800-pound gorilla - the federal governmentalmost certainly could not require other levels of government to increase the transparency of their actions: such interference would constitute commandeering beyond the constitutional pale. ${ }^{19}$ Thus, even if some governments increase transparency in lawmaking, absent a concerted effort across various governments (which would seem very far-fetched), some lawmaking by some governments will remain relatively opaque. A blind spot might also arise by virtue of the ability of both legislatures and agencies to promulgate the law. As noted above, federal administrative law requires a degree of transparency from certain agency actions, but as a rule it does not apply to legislative action. ${ }^{120}$

115. See Masur \& Nash, supra note 9 , at 426-27.

116. Cf. Pub. Citizen v. U.S. Dep't of Just., 491 U.S. 440, 453-54 (1989) (finding it unfathomable that Congress could have intended the federal sunshine statute to apply to meetings between the President and an American Bar Association committee concerning the qualifications of potential federal judicial nominees).

117. See, e.g., Jim Rossi, Participation Run Amok: The Costs of Mass Participation for Deliberative Agency Decisionmaking, 92 Nw. U. L. REv. 173, 233-34 (1997).

118. See, e.g., id. at 234.

119. See, e.g., Jonathan Remy Nash, Doubly Uncooperative Federalism and the Challenge of U.S. Treaty Compliance, 55 Colum. J. TRANSNAT'L L. 3, 18-19 (2016) (discussing the constitutional anti-commandeering principle).

120. By its terms, the National Environmental Policy Act (NEPA) imposes some requirements for agency disclosure with respect to "proposals for legislation . . . significantly affecting the quality of the human environment." 42 U.S.C. $\S 4332(C)$. In practice, however, 
Fourth, and potentially most problematic, greater transparency might adversely affect the quality of legal output from the government. Transparency might impede collegial interactions among multiple decision makers. ${ }^{121}$ This alteration to the decision-making process might derail some proposals that otherwise would have been enacted and affect the content of laws that are promulgated. ${ }^{122}$ While it is impossible to assess a counterfactual accurately, there is a substantial likelihood that these changes to the promulgated substantive law may be negative ones. ${ }^{123}$

\section{B. Intellectual Property for Predictive Information}

A canonical response to a public goods problem of underproduction is to create property rights in the good. ${ }^{124}$ The property right allows the owner to internalize all of the benefits of producing or developing the good, which in turn creates an incentive for the owner to invest in producing the good up to the point at which the marginal benefit of doing so equals the marginal cost. ${ }^{125}$ This is how real property functions - owners have an incentive to invest in the improvement of their land (constructing buildings, etc.). ${ }^{126}$ This is also the basis for intellectual property law, principally patent and copyright. ${ }^{127}$ If intellectual property law did not exist, and anyone could freely use ideas or expression, inventors and creators would have greater difficulty capturing the benefits of their own work. ${ }^{128}$ Anyone could make use of a new technological innovation without paying its creators; anyone could copy and distribute a new novel or movie without paying its author. ${ }^{129}$ By giving inventors

agencies generally do not undertake compliance with NEPA when it comes to legislative proposals. See, e.g., Environmental LaW Institute, Law of Environmental Protection $\S 10: 14(2021)$.

121. See, e.g., Rossi, supra note 117, at 230 ("Private discussions between agency members help promote collegiality which, in turn, improves the quality of agency decisions.").

122. See, e.g., id. at 230-31.

123. See, e.g., id. at 230; David E. Pozen, Transparency's Ideological Drift, 128 YALE L.J. 100, 158-59 (2018) (noting transparency's "diminishing marginal returns").

124. See Mark A. Lemley, The Economics of Improvement in Intellectual Property Law, 75 Tex. L. Rev. 989, 994-97 (1997); Pamela Samuelson, Randall Davis, Mitchell D. Kapor \& J.H. Reichman, A Manifesto Concerning the Legal Protection of Computer Programs, 94 Colum. L. Rev. 2308, 2337 n.92 (1994).

125. See Henry E. Smith, Intellectual Property as Property: Delineating Entitlements in Information, 116 YALE L.J. 1742, 1784-87 (2007) (demonstrating that the exclusionary nature of property rights reassures the owner that their investment will be protected, incentivizing owners to produce goods at optimal levels).

126. William M. Landes \& Richard A. Posner, The Economic Structure of INTELleCtuAl PROPERTY LAW 13 (2003).

127. See id. at 13-14 (explaining that the dynamic benefits of property rights also affect intellectual property rights. Intellectual property law enforces these rights, allowing for creators to develop their products without fear of competitors duplicating their ideas and producing similar goods without bearing the costs of the initial creators).

128. See Mark A. Lemley, Ex Ante Versus Ex Post Justifications for Intellectual Property, 71 U. Chi. L. Rev. 129, 129-30 (2004); Gregory N. Mandel, The Public Perception of Intellectual Property, 66 FLA. L. REv. 261, 269-70 (2014).

129. See Mandel, supra note 128, at 269 (explaining that without intellectual property law 
and creators property rights in their ideas and expressions, intellectual property law aims to allow them to capture more of the value of their own works, and thus in turn provides greater incentives for them to invent and create in the first place. ${ }^{130}$

As things stand, privately held regulatory information is effectively protected as a trade secret. The firm holding the information is under no obligation to disclose it, and outsiders cannot learn the information unless it is voluntarily shared or unless they engage in illegal industrial espionage. In theory, a trade secret of this type could perform the same function as a standard intellectual property right. ${ }^{131}$ A rule protecting such a trade secret could allow the firm that acquires and develops the information to internalize all of the benefits of that information by using or selling it as it sees fit.

As promising as a trade secret solution might seem, it will not be workable for two reasons. First, while individual pieces of regulatory information will be valuable, they will not be nearly as valuable as multiple pieces of such information. The real goal is assembly: bring all available information into the public domain, thereby allowing dispersed parties to utilize that information in their decision-making. ${ }^{132}$ Trade secrets make this type of assembly nearly impossible. Contracting over trade secrets is difficult, for well-understood reasons. The main one is Arrow's Information Paradox: it is difficult to convey the value of information in a reliable fashion without simultaneously conveying the information itself, at which point the contract becomes pointless. ${ }^{133}$ As challenging as these negotiations would be when two parties are involved, they become even more intractable in a multilateral setting. One could imagine the creation of some sort of information clearinghouse, akin to a patent pool, in which various firms contribute available information and buyers purchase access to the sum total of that information. But setting up this type of institution, and negotiating payments among the firms that contribute to the pool, would be equally arduous. Indeed, the challenge of contracting over trade secrets is one of the primary arguments in favor of patents as an alternative. ${ }^{134}$

protection it would not be possible to stop the repeated copying and redistribution of a created work); see also Lemley, supra note 128, at 129 (noting that it is much cheaper to copy a work than to create one, making it unlikely that people will produce more goods instead of stealing an already completed work in a world without property rights).

130. See Lemley, supra note 124, at 993-96 (showing that absent intellectual property law, creators are not incentivized to develop new products as it is unlikely they will recover their costs of development, let alone make money from the product; intellectual property law has incentivized creation by constructing a safer environment where creators can develop their products and test their viability on the market as opposed to against competitors offering the same product at lower prices).

131. See generally Mark A. Lemley, The Surprising Virtues of Treating Trade Secrets as IP Rights, 61 Stan. L. ReV. 311 (2008).

132. Cf. Lee Anne Fennell, Fee Simple Obsolete, 91 N.Y.U. L. Rev. 1457, 1506-08 (2016) (discussing the analogous problem of land assembly).

133. See generally Kenneth J. Arrow, Economic Welfare and the Allocation of Resources for Invention, in THE RATE AND DiRection of InVENTIVE ACTIVITY: ECONOMIC AND SOCIAL FACTORS 609 (Univs.-Nat'l Bureau Comm. for Econ. Rsch., Comm. on Econ. Growth of the Soc. Sci. Rsch. Council ed. 1962) (describing the famous information paradox).

134. See generally Jonathan M. Barnett, Intellectual Property as a Law of Organization, 84 S. CAL. L. REV. 785 (2011) (describing how patents can be used to avoid the contracting 
Accordingly, it is worth considering whether the government should create property rights in information on the likelihood of regulatory action in order to alleviate the public goods problem. A property right in this type of information would, like a standard intellectual property right, give the source of the information the exclusive right to use the information for its own benefit or license that right to another party. So, for instance, suppose that Wind Co., our hypothetical wind turbine manufacturing firm, spends several million dollars lobbying in favor of the Green New Deal. Suppose that, in the course of those lobbying efforts, Wind Co. learns that key members of the Senate support passage of the Green New Deal. This is valuable predictive information. By spending resources unearthing and developing this information, Wind Co. has created a public good. It would now be to the benefit of many other firms and individuals for this information to become public, just as the public benefits when an innovative firm makes scientific knowledge public. Perhaps the way to encourage the expenditure of such resources would be to grant Wind Co. a property right in this information.

Yet to describe the possibility with such specificity is to demonstrate its insurmountable weaknesses. In theory, granting property rights in information should be a means of creating greater incentives for the production of such information. In reality, however, a property right in this type of predictive information will be impossible to enforce and thus useless. Suppose Wind Co. publicizes its information about the Senate and then threatens to sue anyone who makes use of the information without paying for a license. How will Wind Co. ever know if another firm has used the information? What would be the telltale markers of use? If another firm takes some action-increasing production, decreasing production, or investing in a new venture - how will Wind Co. be able to determine whether those actions had anything to do with the information it developed? How will it be able to prove that the other firm's actions were influenced by its knowledge of Wind Co.'s information?

The problem stems from the fact that regulatory information is only useful as an input into some other type of corporate decision - whether to pursue a new line of business, construct a new factory, purchase a stake in another firm, and so forth. The information's role in that decision is opaque to the outside world: it is impossible to determine what role the information might have played simply by observing the decision. Indeed, in some cases, the decision might manifest itself as inaction-a firm might decide to stand pat. This makes the property right essentially impossible to enforce.

Contrast this situation with typical intellectual property rights, such as patents. When a firm infringes a patent, that infringement can be discerned from the face of the infringer's activities. The infringer's product or service would necessarily incorporate the patented invention. For instance, suppose a firm patents a process for curing rubber. ${ }^{135}$ If another firm is using the same process, it infringes the patent. The process itself is identifiable - it is not merely an input into a black box that cannot be opened. The closest analogue to the type of property right we are hypothesizing here is probably the "hot news" doctrine. Under that doctrine, a firm, such as a

problems created by Arrow's Information Paradox).

135. See Diamond v. Diehr, 450 U.S. 175, 181-92 (1981). 
newspaper or wire service, that develops a piece of news has a limited property right in that news. ${ }^{136}$ The concern that motivated the creation of property in "hot news" was the fear that no firm would want to invest substantial funds in uncovering news, only to see that news copied and rebroadcasted by another firm that did not pay the upfront fixed cost. However, even the "hot news" property right is much easier to enforce than a property right in regulatory information. With hot news, the information protected by a property right is itself a final product, not a mere input. The infringing act is publication of the news itself, not use of the news in some other type of decision or process. Thus, it will be evident when a property right in hot news has been infringed: it is infringed whenever the news is published by an entity that does not own a license to the property right. Holders of a property right will not have to guess at how the news was used; it will be evident from the face of the publication.

Consequently, we do not view a property right in regulatory information as a workable solution to the public-goods problem we have identified. Despite the theoretical attraction of such an approach, the practical problems with implementing and enforcing such a property right cannot be overcome.

\section{Regulation Requiring Societal Actors to Engage in Predictions}

Finally, consider the possibility that government might simply mandate the disclosure (or even production) of regulatory information via prediction-forcing regulation. One possible form of prediction-forcing regulation is regulation that requires regulated entities to undertake predictions about future government action. At the outset, it may strike the reader as odd that the government would ask private actors to predict the likelihood of some action that the government itself might take. Why not just require the government to disclose the relevant information itself?

As we note above, simply requiring greater governmental transparency would be preferable - if it could be implemented effectively. But for a variety of reasons, we doubt that such augmented transparency rules would be successful in flushing out additional government information. The collateral costs of requiring governmental transparency might also be high. We think, therefore, that it is worth considering whether it might be possible to obtain socially valuable information from private parties outside of the government. We fully recognize the irony of asking private parties to supply information about the government because the government cannot be trusted to abide by the rules and supply the information itself. Forcing private parties to do something that the government should be doing borders on being a parody of how good governance normally operates. Nonetheless, in a context where no other good options present themselves, prediction-forcing regulation is worth consideration.

Indeed, lest the reader think that our imaginations have run away with us, ${ }^{137}$ we hasten to note that at least one type of prediction-forcing regulation already exists.

136. See Int'l News Serv. v. Associated Press, 248 U.S. 215, 234-45 (1918).

137. Under existing law, corporations can validly hedge predictions about future government policy. $C f$. Grae v. Corr. Corp. of Am., No. 3:16-cv-2267, 2017 WL 6442145, at *17 (M.D. Tenn. Dec. 18, 2017) (noting that defendant corporation's argument that it couched its predictions about how its business depended on stability in government policy "would be persuasive if [defendant] were being sued for simply having failed to predict the [change in 
An extant example can be found in a 2010 SEC interpretive guidance document (the Interpretation). ${ }^{138}$ This document mandates that public companies, as part of their public disclosure, make predictions about the prospects for passage of new laws and regulations governing climate change. The Interpretation directs firms to make these disclosures as part of the "management's discussion and analysis of financial condition and results of operations" or "MD\&A," just as they would be required to disclose the effect of actually enacted climate change legislation or regulation on the firm's business. ${ }^{139}$

Under the Interpretation, a firm must determine whether climate change legislation or regulation - be it at the federal, state, local, or international level ${ }^{140}$ is "reasonably likely" to be enacted. ${ }^{141}$ Indeed, the Interpretation requires the firm to predict not only whether particular legislation or regulation will be enacted, but also the precise timing and scope of that regulation. ${ }^{142}$ The Interpretation also creates a presumption that pending legislation or regulation will be enacted absent an affirmative determination to the contrary by the firm. ${ }^{143}$ If the firm determines (or merely assumes) that the legislation or regulation in question is reasonably likely to be enacted, it must then disclose whether that regulation "is reasonably likely to have a material effect on the registrant's financial condition or results of operation."144

government policy]," but that the argument was unavailing where the plaintiff had made clear that "its claims are premised not on a failure to predict, but on [defendant's] failure to give a full and truthful contemporaneous representation of the business fundamentals and client relationships on which an investor's own prediction could be based").

138. Interpretation, supra note 25. The Interpretation remains in effect today. See id.

139. Information disclosure regimes can have numerous uses (some perhaps unintended by those who originally generated them). See Steven A. Bank \& George S. Georgiev, Securities Disclosure as Soundbite: The Case of CEO Pay Ratios, 60 B.C. L. REv. 1123 (2019). Along these lines, we note the possibility that not only could the Interpretation provide society with valuable predictive information about future government action, but it could also provide regulators with predictions about how societal actors would respond to possible new legal and regulatory approaches. The predictions, in other words, could form a two-way street. Cf. Yoon-Ho Alex Lee, A Model of Stock-Market-Based Rulemaking, 23 Am. L. \& Econ. Rev. 1 (2021).

140. See Interpretation, supra note 25, at 6295-96; U.S. Gov'T AccountaBiLITy OfF., supra note 25 , at 9 .

141. Interpretation, supra note 25 , at 6295 (footnote omitted) ("[M]anagement must evaluate whether the pending legislation or regulation is reasonably likely to be enacted."). The Interpretation thus does not require disclosure with respect to pending legislation or regulation when the rule's enactment is unlikely, even if the pending legislation or regulation would have a large-magnitude effect if enacted. For an argument that societies generally neglect, to their detriment, low-probability, high-magnitude future possibilities, see Jonathan B. Wiener, The Tragedy of the Uncommons: On the Politics of Apocalypse, 7 GloBAL POL. 67 (2016).

142. Interpretation, supra note 25, at 6296 ("In addition to disclosing the potential effect of pending legislation or regulation, the registrant would also have to consider disclosure, if material, of the difficulties involved in assessing the timing and effect of the pending legislation or regulation.").

143. Id. ("Unless management determines that it is not reasonably likely to be enacted, it must proceed on the assumption that the legislation or regulation will be enacted.").

144. $I d$. 
In practice, the Interpretation has not yielded much in the way of predictive information. Empirical evidence indicates that the 2010 Interpretation has had little effect on the content of corporate SEC filings. ${ }^{145}$ This could be the result of lax enforcement (even during the Obama Administration, under the watch of which the SEC originally promulgated the Interpretation), ${ }^{146}$ the manipulability of predictive analyses, ${ }^{147}$ or (at least for large firms) the small effects of possible climate change regulation on firms relative to firms' total operations. ${ }^{148}$

Even if the Interpretation were perfectly enforced and its requirements clear and subject to limited manipulability, there would be reason to doubt the true effectiveness, or desirability, of the Interpretation's approach. In fact, the Interpretation's prediction-disclosure requirements can give rise to perverse incentives with respect to registrants' behavior, and also potentially with respect to the output of legislatures and regulatory agencies.

In order to explain these perverse results, we describe the decision tree faced by a registrant considering pending climate change legislation or regulation. We assume that a registrant will choose the means of complying with the Interpretation that imposes the least cost on the firm. Assume that there is proposed climate change legislation or regulation that falls within the ambit of the Interpretation. The registrant must decide whether to undertake an analysis of whether or not that legislation or regulation is "reasonably likely" to be enacted. One would expect the registrant to make a quick (and inexpensive) initial determination as to whether the registrant can show that the pending legislation or regulation is reasonably likely to

145. See Rick E. Hansen, Climate Change Disclosure by SEC Registrants: REvisiting the SEC's 2010 Interpretive Release, 6 BROOK. J. CORP. FIN. \& COM. L. 487, 526-33 (2012) (finding only minimal increase in climate change risk disclosure post-Interpretation, both in terms of number of filers disclosing risk and scope of discussion among those filers who did discuss climate change risk); $i d$. at 521-26 (reviewing earlier post-Interpretation empirical studies); see also Kevin L. Doran \& Elias L. Quinn, Climate Change Risk Disclosure: A Sector by Sector Analysis of SEC 10-K Filings from 1995-2008, 34 N.C. J. INT'L \& COM. REG. 721 (2009) (empirical analysis of climate change risk disclosure pre-Interpretation, from 1995 to 2008); Camden D. Burton, An Inconvenient Risk: Climate Change Disclosure and the Burden on Corporations, 62 ADMIN. L. REV. 1287, 1296-98 (2010) (describing general paucity of climate change risk disclosure pre-Interpretation); Hansen, supra, at 508-14 (surveying preInterpretation empirical studies).

146. See David Gelles, S.E.C. Is Criticized for Lax Enforcement of Climate Risk Disclosure, N.Y. TIMES (Jan. 23, 2016), https://www.nytimes.com/2016/01/24/ business/energy-environment/sec-is-criticized-for-lax-enforcement-of-climate-riskdisclosure.html [https://perma.cc/SD57-SZHJ] ("In the two years after the interpretive guidance, the S.E.C. issued 49 comment letters to companies addressing the adequacy of their climate change disclosures. But it issued only three such letters in 2012 and none in 2013.").

147. But see GAO Says Climate Change Disclosure Requirements Are Clear, THOMSON Reuters Tax \& ACCT. News, March 27, 2018, at 1 ('The SEC's disclosure requirements concerning risks associated with climate change are clear with its 2010 interpretive guidance and staff review of company's filings, the Government Accountability Office said.").

148. See George S. Georgiev, Too Big to Disclose: Firm Size and Materiality Blindspots in Securities Regulation, 64 UCLA L. REV. 602, 641 (2017) (footnote omitted) ("[A] large firm may be able to justify complete non-disclosure if it can absorb the effects of climate change on its business, even when those effects are sizeable in absolute terms."). 
become law. Call the probability that the law or regulation will be enacted $p$. If the registrant believes that $p$ is reasonably high, then the registrant should rationally rely on the presumption that the legislation or regulation will become law "[u]nless management determines that it is not reasonably likely to be enacted." ${ }^{149}$ In that case, then, the registrant will have to make disclosures as if the proposed legislation or regulation were to become law. ${ }^{150}$ Call the costs of such disclosure $C_{d \cdot}{ }^{151}$

On the other hand, the registrant may believe that it can make the required showing that the legislation or regulation is not reasonably likely to become law. In that case, the registrant could avoid disclosure and its accompanying costs. Presumably, however, there will be some cost in undertaking a satisfactory prediction analysis demonstrating that the legislation is unlikely to be enacted. Call that $\operatorname{cost} C_{p} .{ }^{152}$ If $C_{p}>C_{d}$, then we would expect the firm to choose disclosure over a prediction analysis, even if the firm believes that $p$ is actually quite low. The firm will undertake a prediction analysis only if the costs of disclosure are quite high. Figure 1 summarizes these possibilities.

149. Interpretation, supra note 25 , at 6296.

150. Determining what would become law, and anticipating changes to pending legislation or regulation, would likely require some predictive analysis. Thus, reliance on the presumption would seem to require the registrant to assume that the actually pending legislation or regulation becomes law.

151. Disclosure costs might include the costs of assembling the relevant data to disclose, the cost of disclosing information that might reveal publicly certain corporate information, and the impact on the corporations' financial status resulting from a reduction in stock price following the disclosure.

152. Predictive analysis costs would include the costs of assembling the relevant data to support a prediction analysis. One might think that a corporation might like to have a legal opinion in hand indicating that the pending legislation or regulation is not likely to become law; such a legal opinion would also have a cost. We assume that predictive analysis costs will only be undertaken after an initial review of the situation. Given that, it may well be that a corporation will only devote substantial resources to a predictive analysis if the corporation is convinced that a law firm will issue a satisfactory legal opinion on the likelihood that the pending legislation or regulation will not be enacted. However, it might be suggested that a legal opinion is not a sure thing; if that is the case, then predictive-analysis costs would also include the cost of investing in a predictive analysis only to find that disclosure is required at the end of the day. Such a possibility would also make Diagram 2 in the text more complex but would not change the bottom-line result. 
Figure 1. Registrant Decision-Making in Light of the Interpretation

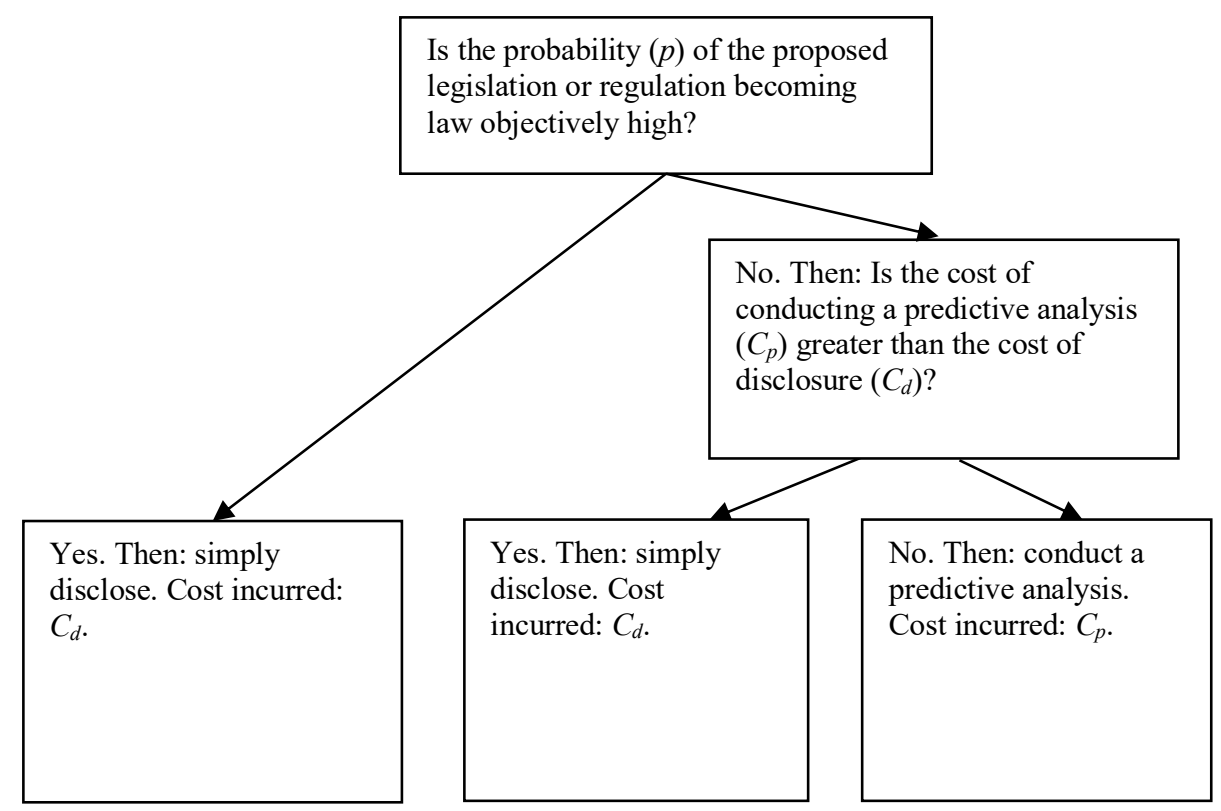

Note, however, that there is a potential endogeneity here: it may be the case that a firm can lobby so as to reduce the probability that legislation or regulation will become law. ${ }^{153}$ This lobbying activity could reduce the original probability, $p_{0}$, that the proposal will become law to a much lower post-lobbying probability, $p_{1}$. Of course, putative regulated actors may have an incentive to lobby to ensure that proposed legislation or regulation does not in fact become law, irrespective of the Interpretation. The point here is that regulated actors may have an additional incentive to lobby to ensure that any proposal never reaches the point where it might be said with reasonable likelihood that the proposal might become law. This could come to pass through focused lobbying on those legislators who control the agenda or on marginal committee members who might effectively decide whether or not a bill advances beyond the committee. Call these additional marginal lobbying costs Cl.

Engaging in this additional lobbying and expending $C_{l}$ will only make sense if, once the probability of passage has shifted from $p_{0}$ to $p_{l}$, the actor will still find it worthwhile to expend $C_{p}$ in order to avoid the costs of disclosure $C_{d}$. That is, lobbying will only make sense if $C_{l}+C_{p}<C_{d}$.

This more nuanced version of affairs is summarized in Figure 2.

153. It is conceivable as well that a corporation might opt not to lobby precisely because lobbying against a bill might be seen to increase the salience of the bill and thus increase the likelihood (for purposes of the Interpretation) that the bill will become law. (We are grateful to Sasha Volokh for this point.) 
Figure 2. More Nuanced Registrant Decision-Making in Light of the Interpretation

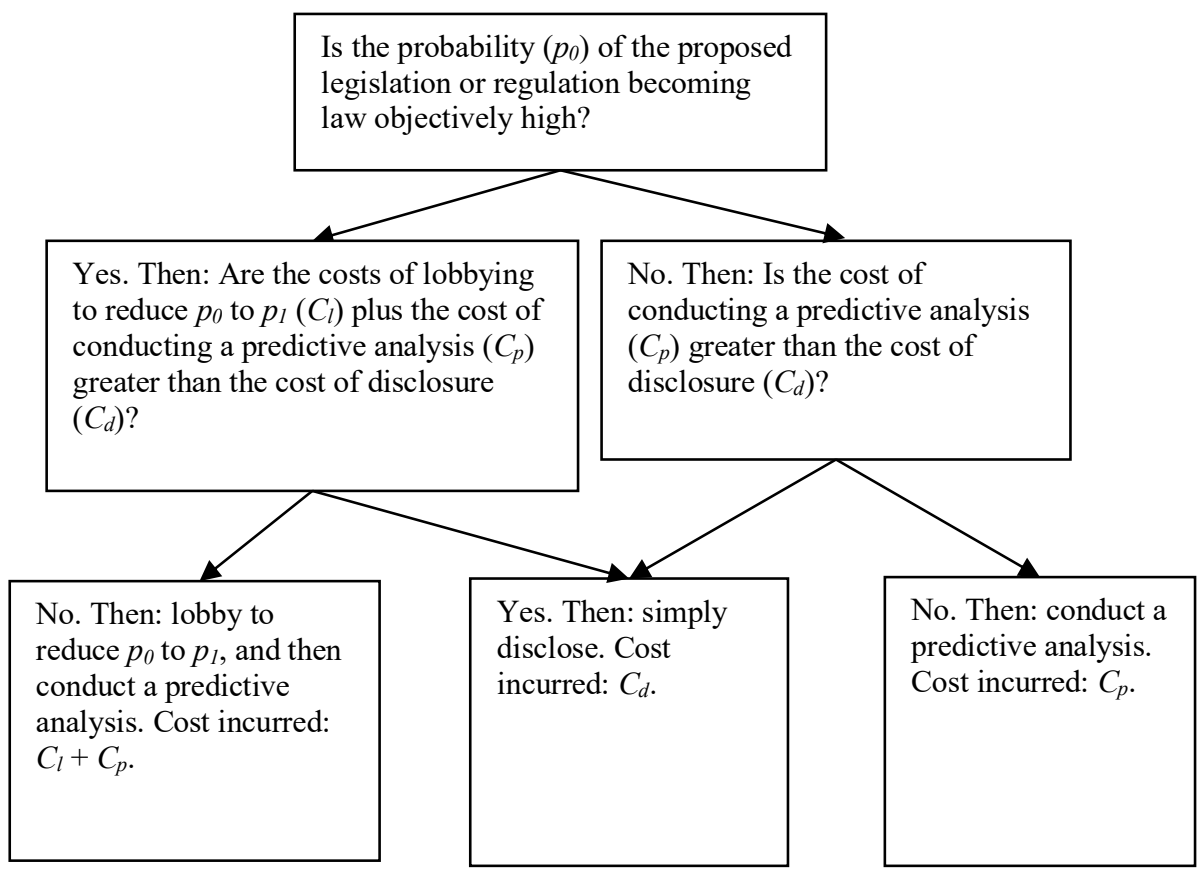

Note, moreover, that as part of its strategy to reduce the chances that a proposed climate change legislation or regulation will be enacted, a firm might lobby for some other piece of legislation or regulation, possibly on a completely unrelated issue. This could be in addition to or in lieu of lobbying against the proposed legislation or regulation in question. Legislatures and regulators are capacity constrained; consideration of Proposal $A$ limits their ability to consider Proposal $B$ as well. Thus, by devoting resources to advancing competing legislation and regulation, a corporation might reasonably expect to reduce the probability that climate change legislation and regulation is successfully enacted. ${ }^{154}$

The SEC's Interpretation thus has two significant flaws. It provides an easy escape hatch via the presumption that a statute or regulation will be enacted, allowing firms to avoid offering a prediction. And it creates incentives for firms to lobby for or against various measures simply in order to avoid disclosure. Nonetheless, the Interpretation points the way toward a more effective form of mandated regulatory prediction.

Prediction-forcing regulation could assume a number of different forms. One could imagine an agency issuing a prediction-forcing regulation regarding matters within its own purview - the EPA requiring predictions of environmental legislation,

154. Such an approach would be similar to the practice of business interests that fund advertisements supporting or opposing candidates for judicial office that focus on issues more salient to the public-at-large, such as issues of criminal law, even though the business interests themselves care much more about economic issues. See, e.g., Lawrence Baum, Judicial Elections and Judicial Independence: The Voter's Perspective, 64 Онго Sт. L.J. 13, 34-37 (2003). 
for instance. Or one could imagine a generalist agency, such as the SEC, requiring firms to predict any relevant legislation or regulation across all potential areas of law. An ideal prediction-forcing regulation would obligate regulated parties to make predictions regarding the probability that potential legislation or regulation relevant to their business will become law. In addition, the regulated firm could be required to disclose the information on which it has based its prediction-essentially converting this information from a trade secret into public knowledge.

There is obviously quite a lot bound up in the question of what constitutes "potential" regulation or legislation. Firms should not be required to speculate about any conceivable regulation that might exist in the imagination of some regulator somewhere. There are a few possible approaches to solving this problem of scope. One would be for the regulator who promulgates the prediction-forcing regulation to specify a list of potential regulations or law that seem at least plausible or have become publicly salient. Another would be to require firms to offer predictions on any legislation or regulation that they believe crosses some threshold of probability - say, ten percent. If a firm declined to offer a prediction on a particular potential regulation, that would signal that the firm believed the regulation to be less than ten percent likely. We can imagine other similar ways of addressing scope. The point is that it should not be especially difficult to draw reasonable boundary lines when defining a firm's disclosure obligation.

At the same time, a prediction-forcing regulation would only exacerbate the public-goods problem that animated our inquiry in the first place. Prediction-forcing regulation would encourage the dissemination of existing information, to be sure, but it would dampen firms' enthusiasm to collect that information in the first place by effectively forcing them to disclose it publicly. This would limit the extent to which firms could gain competitive advantages by collecting such information. With less to gain, firms would be willing to expend fewer resources to collect the information in the first place. ${ }^{155}$ For this reason, it is hard to be overly optimistic about the success of prediction-forcing regulation at addressing the underlying problem of legal and regulatory risk.

\section{CONCLUSION}

The ability to predict future regulatory change is important to private firms, and it is important to society at large as well. But formulating accurate predictions can be immensely challenging. Information is dispersed among many governmental actors, and governmental authority itself is dispersed among many jurisdictions and branches. In this Article, we analyzed several potential responses to this problem. Some-like creating private property rights in predictive information-strike us as utterly unworkable. Others-such as greater government transparency and prediction-forcing regulation-offer slightly greater promise, though coupled with significant shortcomings and hurdles.

155. This is the same concern that has generally prevented courts from imposing duties to disclose in contract law. Ariel Porat, A Comparative Fault Defense in Contract Law, 107 Mich. L. REV. 1397, 1400 (2009) (emphasis in original) ("Traditional American contract law does not impose any duty to disclose information at the performance stage."). 
One possible problem shared by several of the methods we have discussed is that they could potentially cause a deterioration in the substantive content of government legal output. The increase in private actors' ability to accurately predict future government behavior may alter the very government behavior that private actors seek to predict. ${ }^{156}$ A prediction market may invite investors to lobby the government in order to encourage (or discourage) certain action, which would have an impact on legal content. ${ }^{157}$ Greater government transparency may affect government decision making, which would have an impact on legal content. ${ }^{158}$ Prediction-forcing regulation may encourage corporations subject to reporting requirements to lobby for certain actions (or even to lobby for certain unrelated government actions in order to derail other government actions), which would have an impact on legal content. ${ }^{159}$ And a private insurance market with respect to government action might invite moral hazard on the part of policyholders, which would have an impact on legal content. ${ }^{160}$

We cannot say per se, or in any particular case, whether the change in legal output will be substantial or insubstantial, or detrimental or beneficial. However, there is good reason to think that, at least sometimes, the effects will be substantial and detrimental. ${ }^{161}$ Given that potential, policymakers must judge whether the loss of having less desirable laws (on the whole) outweighs any benefit to be gained from facilitating more accurate predictions of future government behavior.

156. In quantum physics, this notion is encapsulated in the Heisenberg Uncertainty Principle. See Werner Heisenberg, Physics and Beyond: Encounters and Conversations 76-81 (Ruth Nanda Anshen ed., Arnold J. Pomerans trans., 1971). Scholars have found that the principle has application to human and institutional actors as well. See, e.g., Robert E. Kraut \& John B. McConahay, How Being Interviewed Affects Voting: An Experiment, 37 Pub. OpINION Q. 398, 406 (1973); Ronald J. Krotoszynski, Jr., The Heisenberg Uncertainty Principle and the Challenge of Resisting - or Engaging - Transnational Constitutional Law, 66 Ala. L. Rev. 105, 108 n.10 (2014).

157. See supra note 88 and accompanying text.

158. See supra notes $118-20$ and accompanying text.

159. See supra notes $150-51$ and accompanying text.

160. See Masur \& Nash, supra note 9, at 412-15.

161. See supra note 121 and accompanying text. 